Florida International University FIU Digital Commons

FIU Electronic Theses and Dissertations

University Graduate School

$11-8-1991$

\title{
Rural mobilization in southern Peru, 1900-1962 : the case of La Convención
}

Mari M. Conea-Rosenfeld

Florida International University

DOI: $10.25148 /$ etd.FI14060891

Follow this and additional works at: https://digitalcommons.fiu.edu/etd

Part of the Latin American Studies Commons

\section{Recommended Citation}

Conea-Rosenfeld, Mari M., "Rural mobilization in southern Peru, 1900-1962 : the case of La Convención" (1991). FIU Electronic Theses and Dissertations. 2421.

https://digitalcommons.fiu.edu/etd/2421

This work is brought to you for free and open access by the University Graduate School at FIU Digital Commons. It has been accepted for inclusion in FIU Electronic Theses and Dissertations by an authorized administrator of FIU Digital Commons. For more information, please contact dcc@fiu.edu. 


\section{ABSTRACT OF THE THESIS}

Rural Mobilization in Southern Peru, 1900-1962: The Case of La Convencion

by

M. Mariana Conea-Rosenfeld

Florida International University, 1991

Miami, Florida

Professor Mark D. Szuchman, Major Professor

The purpose of this thesis is to study the conditions that promoted mobilization against established authority. The analysis of rural mobilization distinguishes from among longitudinal and immediate conditions, the mobilization process itself and the role of the state. The concept of articulation of modes of production examines the processes of rural transformation by following the changing nature of land ownership and patron-client relations.

The evolving patterns of class opposition and alliance reflected directly the state of articulation of capitalist and pre-capitalist modes of production and the process of class formation in the southern Peruvian highlands over the course of the late eighteenth to the mid-twentieth centuries. 


\section{THESIS COMMITTEE APPROVAL PAGE}

To Professors Mark D. Szuchman

Eduardo Gamarra

A. Douglas Kincaid:

This thesis, having been approved in respect to form and mechanical execution, is referred to you for judgement upon its substantial merit.

Dean Arthur Herriott

College of Arts and Sciences

The thesis of Mari M. Conea-Rosenfeld is approved.

A. Douglas Kincaid

Eduardo Gamarra

Mark D. Szuchman, Major Professor

Date of Examination: November 8, 1991

Dean Richard Campbell

Division of Graduate Studies

Florida International University, 1991 


\title{
FLORIDA INTERNATIONAL UNIVERSITY \\ Miami, Florida
}

\begin{abstract}
Rural Mobilization in Southern Peru, 1900-1962:
The Case of La Convencion
\end{abstract}

A thesis submitted in partial satisfaction of the requirements for the degree of Master of Arts in International Studies.

$$
\text { by }
$$

Mari M. Conea-Rosenfeld 


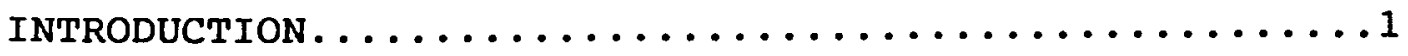

CHAPTER ONE

I. Approaches to Peasant Studies.............6

CHAPTER TWO

I. Rural Protest in Southern Peru: A Historical Review

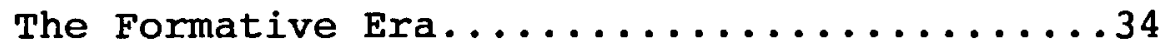

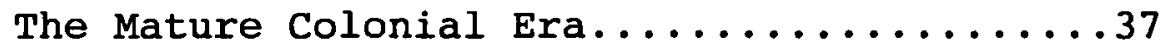

The Formative State Era..............41

II. La Convencion Valley

Area Description .................. 50

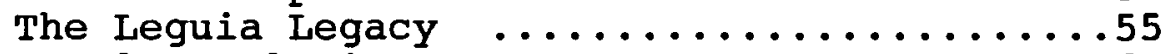

Rural Population ................61

CHAPTER THREE

I. The Hacienda System

The Land......................... 73

The Labor........................ 87

The Patron-Client Relations..........92

CHAPTER FOUR

I. The Protests

The First Stage...................104

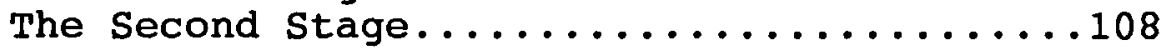

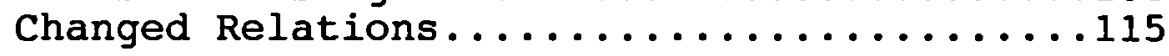

CHAPTER FIVE

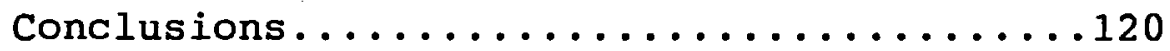

NOTES................................... 135

BIBLIOGRAPHY ........................... 163 


\section{INTRODUCTION}

By the early 1960s, farmers in La Convencion Valley in southern Peru had broken away from the traditional hacienda system that had prevailed for over four centuries. Rural mobilization reached its peak in 1962 when the Peruvian government formally recognized the claims and sanctioned many of the demands of the striking peasant unions. ${ }^{1}$ This process signaled the eventual disappearance of a system of social relationships that had revolved around the institution of the hacienda, reorganizing in the process the social interaction among the peasant communities operating independently of the hacendados. This was realized through the boycott of the hacienda owners by their arrendires in association with allegados and sub-allegados..$^{2}$ Despite its unique scope and success, the general strike of 1962 was but one manifestations of a wider rural movement that developed in La Convencion Valley.

What were the conditions that made this area the seat of rural mobilization? What was the composition of the rural population? Which of the countryside's groups resisted the most? What were the motives for mobilization? How significant were the issues of land, taxes, ethnicity and clientelistic relations? Against whom was the antagonism directed? What distinguished regional from national 
objectives?

Finally, what

political

and

cultural

continuities can be discerned?

To answer these questions, I will look at the local conditions as they are linked to a historical continuum. The settlement and exploitation of La Convencion Valley was a result of multiple events that shaped the institutional arrangements in the adjoining highlands during and after the Spanish presence. Therefore, it is important to account for the different social and economic controls that transformed the people in the highlands, who later migrated to the valley. Moreover, the same institutions would perform the same functions when established in the newly settled areas.

In some areas, capitalism did not emerge from the internal social relations but instead was brought in through colonial or neocolonial connections. In those areas the complexity of social and economic relations is significant. Articulation of modes of production provides the context within which the process of capitalist penetration and the perseverance of noncapitalist cultural, economic, political, and social forms can be explained. Therefore, I will also use the concept of articulation of modes of production to examine the process of rural transformation through the changing nature of land ownership and patron-client relations. Understanding the nature of land ownership is important for tracing the patron-client ties, but in many developing 
societies, such as Peru, personal relationships play a more important role.

The concept of patron-client dynamics helps to reveal the relationship between opposing pairs of classes where the nature of land ownership does not suffice. Patron-client relationships are dyadic alliances that often appear as remedies to institutional deficiencies. The institution of agricultural tenancy provides such a case. Traditional rural patron-client relations tend to prevail in settings where the subordinates are heavily dependent upon the superiors and where the superiors need loyal personal dependents. The subordinates, or clients, are usually unskilled, legally unprivileged, forbidden to organize and generally subject to victimization. If this relationship fulfills such an essential role, what accounts for its decline? Such a relationship breaks down when either of the parties fails to fulfill its part, usually as consequence of changes in material conditions that render the relationship useless.

My analysis of rural mobilization will distinguish between longitudinal, or long-term, and immediate, or short-term conditions, the mobilization itself; and to a lesser degree, the role of the state. Long-term or longitudinal background favoring peasant mobilization will be exemplified by such indicators as the change in the nature of land ownership, new economic activities, altered positions of 
elites, and the process of class formation. The short-term conditions will include the decline in the return for labor, the worsening of market conditions, and the threats to recently achieved gains. The process of mobilization will take into consideration the formation of upward linkages, the nature of internal organization, and the strikes and legal struggles. Finally, I will account for the state's role as a fundamental player in the historical problem of rural mobilization.

A word of clarification with respect to the subject of this study, that is, the peasant. I will use the term peasant to mean a rural cultivator from whom an economic surplus is extracted, freely or coercively, by a nonproducing class. ${ }^{3}$ Thus used, the term is not intended to imply that peasants form a single class.

This work is organized into five chapters. Chapter 1, evaluates the existing theoretical approaches concerning peasant mobilizations. Chapter 2, part one, surveys the history of peasant rebellions in the southern Peruvian highlands from the conquest to the twentieth century; part two, examines the history and special conditions present in La Convencion Valley. Chapter 3, presents an overview of the hacienda system in La Convencion Valley, with its unique characteristics -availability of land and shortage of labor. It also accounts for the development of capitalist 
agriculture, emphasizing the consequences for the tenant-farmer population. Furthermore, it discusses the issues of labor, patron-client relations, and the specific relations of production encountered in the valley up to the period of mobilization. Chapter 4 addresses the issue of the mobilization itself in three stages: first and second protests and the resulting changed relations. Finally, chapter 5 takes up the process of class formation as the outcome of the mobilization and addresses the theoretical considerations that pertain to this case. 


\section{CHAPTER ONE}

\section{Approaches to Peasant Studies}

Western social scientists have long been interested in mobilization among lower classes in developing nations. Karl W. Deutsch introduced the concept of mobilization in the early 1960s, considering it "an essential prerequisite" for modernization. He defines mobilization as

the process in which major clusters of old social, economic, and psychological commitments are eroded... and people become available for new patterns of socialization and behavior including potential or actual involvement in mass politics. ${ }^{4}$

The study of this phenomenon became even more important in the late 1960s, when scholars were trying to explain the events taking place in the Third World. It became apparent, moreover, that the agrarian question was important in understanding development in both the Western and non-Western worlds.

Samuel Huntington, in Political order in Changing Societies, looks at the degrees of institutionalization of a society for evidence of political development.

revolution, like other forms of violence and instability, is most likely to occur in societies 
which have experienced some social and economic development and where the processes of political modernization and political development have lagged behind the process of social and economic change. ${ }^{5}$

By political modernization, Huntington means the mobilization and politicization of new groups into the system; by political development, he conceptualizes the creation of political institutions sufficiently adaptable, complex, autonomous, and coherent to absorb and order the participation of new groups and to promote change.

In Huntington's view, the difference between the city and the countryside increases as consequence of modernization. The expansion of political participation is reflected in the changing relationship between city and countryside and their respectively changing patterns of stability and instability. ${ }^{6}$

In a traditional society, power rests in the hands of the rural elite and is based on the elite's control of land in the countryside along with complete domination over the peasantry. Political participation is low and limited to the clergy, aristocracy, landowners, ranking military, and bureaucracy. With the advent of new economic activities, new social groups emerge. Migration to the cities may involve contact with other groups and the development of a new social consciousness. In countries that come late to modernization, the key to stability lies in the extent to which rural masses, 
the peasants and other strata, are mobilized into politics within the existing political system rather than as external agents bent on the system's liquidation. Huntington writes

the timing and the method and auspices of the Green Uprising thus decisively influence the subsequent political evolution of the society. ${ }^{7}$

But he also stresses that "rural instability is major but avoidable. ${ }^{8}$ In Huntington's analysis, the degree to which mobilized and politicized rural masses are incorporated the system depends on the urban elite, the intellectuals and the military. Huntington recognizes that, although the peasants' actions have important political consequences, they are not capable by themselves of effectuating change.

Barrington Moore's Social Origins of Dictatorship and Democracy represents one of the earliest statements on the role of the peasants. In Moore's analysis, the rise of agrarian capitalism strongly affects the subsequent course of political development. Moore emphasizes the structural differences that develop during the course of modernization, and claims that the character of the link between the peasant community and the overlord is important. ${ }^{9}$ The relationship is conditioned by two factors: availability of land and adequate social institutions to encourage political stability. ${ }^{10}$ 
For Moore, the division of labor and community solidarity are closely related, because in association with new sudden impositions may lead to the development of revolutionary potential of the peasantry. In a radical form of solidarity, the institutional arrangements spread grievances through the peasant community, seek equitable distribution of scarce resources, and turn the peasants into a unified group hostile to the overlord. The conservative type of solidarity, based on the division of labor, inhibits political action, and leads to changes that would be more reformist in nature. This form of solidarity is the more modern phenomenon. ${ }^{11}$

The commercialization of agriculture is not in itself a sufficient condition for rural mobilization. To Moore the elite's reaction to change is critical in determining whether or not there is large scale unrest. The revolutionary potential is not sufficient; to be effective, it must be directed, and it must have allies.

Theda skocpol approaches the study of the peasantoverlord relationship from a similar perspective. ${ }^{12}$ Like Moore, Skocpol, assigns important roles to the peasants and to community solidarity, emphasizing the importance of structural conditions: the degrees and kinds of solidarity in peasant community, the degrees of peasant autonomy or control by landlords or agents, and the relaxation of the state's coercive sanctions against the peasants' collective action. 
It is only with economic and social change that class struggle plays an important role and the peasantry becomes part of it. Skocpol advises that, in examining class relations in the countryside, the analysis of the different strata of property holders is not enough. It may be misleading; hence attention should be given to

the historically specific institutional arrangements by which two analytically basic kind of social relationships are simultaneously established: the relationship of direct producers to one another, to their tools, and to the land in the immediate process of production; and the relationship to the overlord, by which product is extracted from the direct producer by a class of nonproducers. ${ }^{13}$

According to Skocpol, autonomy and solidarity may be built on these agrarian structures, depending upon the institutional form they take: serfs, laborers, a rentier agrarian system with smallholder peasant communities. The nature of the ties, which define the method of appropriation, is important in the analysis of the penetration and development of capitalism. Furthermore, Skocpol attempts to establish a pattern of peasant behavior that 
transcends spotty and localized unrest and that accomplishes something very different from peasant based rebellions. ${ }^{14}$

That is, the timing of the peasants' revolutionary potential in conjunction with the political crises of the autocratic states in the context of world historical development is of essence.

Joel Migdal, in Peasants, Politics and Revolutions, provides a systematic theory of how imperialistic modernizing forces impinge on peasant villages, and how peasants in turn are likely to respond.

in the past fifty years, peasants in certain areas have engaged in prolonged national struggle to change the system of government and the distribution of power. These movements have not been based on a sudden burst of violence after frustration was built, as was often true, of spasmodic, anomic peasant rebellions of the past centuries. Rather, peasants in these cases have engaged in a long drawn -out revolutions in a variety of institutionalized ways -as political cadres, as disciplined soldiers, as loyal suppliers of food, money and shelter, and as active and 
passive members of a host of revolutionary organizations and groups. ${ }^{15}$

Here Migdal is concerned with how an anomic revolutionary participation became institutionalized. He argues that in the twentieth century, developing countries have been undergoing disruptive economic transitions from a predominantly "inward-orientation" marked by subsistence agriculture and strong communal and patronage control to an "outward-orientation" marked by substantial involvement of individual peasants and households with extra-local markets, cash, and wage labor. ${ }^{16}$ According to Migdal, the peasant who undergoes the most rapid exposure to the market forces would be the one to respond to political stimuli, to get involved in movements that offer solutions to market-induced problems. The traditional peasant, in Migdal's analysis, by wanting to maintain the status quo, defends his minimal security, becomes more inward oriented, and so eventually develops into a revolutionary.

Migdal claims that newly strengthened national states, with their extensive bureaucratic apparatus, are instrumental in developing a form of capitalism, which promotes commercialization and affects agrarian class relations and peasant communities and thus is the root of peasant-based revolutions. But the peasantry, he also acknowledges, is weak in organizational ability, possessing relatively little 
education or organizational expertise. Consequently, the mobilization of the peasantry will be preceded by the development of a superstructure by external leaders.

Migdal acknowledges the usefulness of the concept of culture contact, but cautions that attaching too much significance to it may create distortion,

Culture contact as an explanation fails to take account of the differentiation between two distinct concepts in social science, social mobilization and modernization. ${ }^{17}$

Migdal advises that to rely too much on the culture contact concept may not suffice in understanding cases where social mobilization did take place but did not lead to modernization, such as in the case of certain millenarian movements. Because simple exposure to the modern is not sufficient to change culture, an experience such as an economic crisis will cause structural changes in favor of the outward-oriented forces. Therefore, Migdal emphasizes that historical forces have to be considered in the context of the specific pressures peasants face in their relationship with other classes.

Eric Wolf also acknowledges the effects of the spread of capitalism, in Wolf's case "North Atlantic capitalism." It is largely as a consequence of this process that land and labor 
became commodities. According to Wolf, industrialization and expanded markets gave rise to new social arrangements that would affect the peasants, who were as yet unsure of their own social positions and interests but forced by the imbalance of their lives to seek adjustments. ${ }^{18}$

At this stage, Wolf emphasizes the importance of peasant community solidarity and its degree of autonomy. Thus, "dislocated" peasants become available to engage in organized political efforts to effectuate change. Furthermore, not all peasants become active. The middle and land-free are the likeliest candidates,

because the former are thoroughly caught up in the tension of transition from rural agrarian economy to an urban capitalism, and the latter are the least subject to the power of the landlords and to continuing attachment to the land. ${ }^{19}$

The very attempt of the middle peasants to remain traditional is what makes them revolutionary. For Wolf, the crucial insurrectionary capacity is exhibited by communal holding peasants, in the material and organizational advantages their situation offers for collective resistance against the outside pressures. In this sense Wolf and Migdal arrive at similar conclusions. Wolf declares that the peasant 
middle stratum would be most likely to mobilize for action and would need leadership from outside the community:

poor peasants and landless laborers therefore are unlikely to pursue the course of rebellion unless they are able to rely on external power to challenge the power that constrains them. ${ }^{20}$

Wolf suggests that one must analyze more than the situation of the peasantry and the agrarian economy in order to understand peasant participation in social changes. One also must look at the role of the state. Rather than imbuing the state with an active role, as does Skocpol, Wolf's state has a passive role.

At the center of James C. Scott's theory is the village community, where the autonomous social and cultural structures create the peasants' moral economy. The moral economy of the village is a consequence of a local system of action, influence, and authority that is

to some degree isolated from the outside. It constitutes a distinct sphere of perception and information and above all, moral obligation (i.e., social sanctions) that tends to exclude outsiders. Such localism serves to differentiate the village not only from other villages but also from the world of external elites above it. ${ }^{21}$ 
Unlike Wolf or Moore, who describe the peasant communities as unwitting agents of change, scott ascribes to them a more direct role. When faced with the expansion of capitalism in the form of market and the rise of centralized states, peasants turn to the community bonds of solidarity in directing their resistance. ${ }^{22}$ Scott expresses doubt, though, as to whether the peasantry has the cultural and organizational autonomy to resist the regular impact of the hegemony of the ruling classes. ${ }^{23}$ He argues that the landholding play the greatest role in resisting change. Sharecroppers and tenants are unlikely to enjoy any degree of autonomy; therefore they would be less prone to mobilize.

Samuel Popkin's Rational Peasant provides us with another approach to the study of peasant participation in revolutions. Popkin claims that community solidarity approaches tend to overestimate the stability, welfare, and benefits that traditional peasants gain from the patron-client and village relationships. The village institutions have built-in tensions and the population is stratified. For Popkin, the exploitation of the peasant through this patron-client relationship is a permanent incentive for the peasant to seek change. Some peasants may actively try to break out of traditional relationships by developing new ties with traders, middlemen who could offer better opportunities 
Throughout the world, the peasants have fought for access to markets not as a last gasp when all else failed them, but when they were secure enough to want to raise their economic level and "redefine" cultural standards! ${ }^{24}$

Popkin contends that mobilization will occur as a result of individual self-interest, rather than as a function of a pre-existing group solidarity. The individual peasant's development is defined as a

growing ability to organize and struggle for rights and privileges previously denied him. ${ }^{25}$

In Popkin's analysis, the central state is not automatically a threat to the peasantry; on the contrary, it can be an ally in the process of development

[T]he strong peasant property and the absolutist state developed in mutual dependence upon one another. The state increased its power by virtue of its ability to get between the landlord and the peasant, to ensure peasant freedom, hereditability and fixed rents, and thus to use peasant production... as the direct source of revenue for royal strength and autonomy. ${ }^{26}$ 
Popkin's conclusions on the actual organizational abilities of the peasantry coincide with Migdal's: the peasants need outside allies and guidance.

Charles Tilly's work represents the political-conflict approach and, in Lynn Hunt's words,

like E.P. Thompson and George Rude, Tilly wants to rehabilitate the "mob" or what historians less pejoratively label the "crowd."27

Tilly's agenda is historical, and he is interested in how "collective action" in Europe evolved under the long-term structural changes. According to Tilly, the structural changes have altered the means and ends of collective action. In his view, the masses are continuously confronting widespread structural changes which in effect condition the rules of collective action. In the study of the development of collective action on the "ways that people act together in pursuit of shared interests" he acknowledges an evolutionary pattern. Therefore,

the proactive types of collective action appear superior to competitive or reactive types, since with proactive types of collective action such as strikes and demonstrations, ordinary people are able to assert new group claims through formal 
organizations that effectively compete in a national political arena. ${ }^{28}$

Tilly defines collective action as "people acting together in pursuit of "common interest"; he considers this definition is less ideologically loaded than "class struggle." In analyzing "collective action" he is interested in the degrees of organization, the amount of resources under collective control, and their relationship to government and other opposing groups. For Tilly, the goal of collective action is political power. While for Marxist analysts the political contests are aimed at the level of changing social relations of production, for Tilly they are located at the level of changes in the organization of production. When he considers the effects of industrialization, he focuses on long-term structural changes such as proletarianization rather than on social relations themselves.

Tilly calls attention to the importance of interest and opportunity, because

people act collectively to maximize their collective gains, and they do so within the constrains set by the cost of such collective action. ${ }^{29}$

The peasants' dissatisfaction stems from the realization that their material hardships are much worse, and not 
inevitable, and that their goals do not coincide with those of other classes. The peasants' goals are to improve on their immediate economic and social conditions - their life work. Their concern with immediate changes does not set them apart from urban laborers. What differentiates them is that their economic situation is worse than that of the urban proletariat, and the choices available to them.

For the peasantry a more equitable distribution of the land is the prerequisite to economic growth. The ultimate goal of the most peasants is the ownership of the means of production, that is, the land. Therefore, land redistribution becomes an issue of critical importance because it represents not just an increase in the peasants' economic well-being, but a reordering of basic social relationships that had previously existed between the peasant and landlord.

From a Marxist perspective, a reordering of basic social relationship is the goal of the revolutionary struggle; and for a revolutionary strategy to be successful it must be based on a scientific analysis of the existing social reality, and in particular the actual state of class struggle. According to Marx, the preconditions for the rise of capitalism in England and Continental Europe were, first, the dispossession of the peasantry, and second, their employment as wage-laborers . 
Marx did not categorize the peasantry as a social class, although in his analysis of the peasantry under the Bonapartist regime in France, he makes a clear distinction between the "revolutionary" and the "conservative" peasant. Marx studied the conditions under which different kinds of rent arise and the introduction of the money rent presented a departure point for the development of capitalist relations. These conditions would be directly related to differentiation and polarization among the peasants. ${ }^{30}$ Marx was aware that certain elements, if not the entire peasantry, could constitute a revolutionary force against the established order. Furthermore, he points to the urban proletariat as the natural ally and leader of the peasantry.

Lenin, using Marx's conceptualization of the peasantry, developed a more elaborate analysis of the peasants in undeveloped countries. He warned against a rigid interpretation of the Marxist thesis, emphasizing that while the separation of the direct producers from the land is a result of capitalist development, capitalist penetration of the agricultural sector is a slow process. Lenin found that in nineteenth-century Russia, peasants renting land was commonplace, and took three main forms: money rents, sharecropping or produce rents, and labor service. The nature and the amount of rent as well as the obligations were different for different "classes of peasantry." Renting 
served to accentuate the differences within the peasantry. The richer peasants leased more land on a cash rent basis; the poorer ones leased land more on taxing terms, which involved produce rent or labor services. The poorer peasants leased land to subsist and the rich to enlarge their surplus. For Lenin the issue of the nature of tenure, its impact on productivity and change were linked to the totality of class relations. Lenin recognized the crucial role of the peasantry and adapted the Bolshevik program and tactics, at least for the initial stage, to the need to win the peasants' support.

Mao went well beyond Lenin's theoretical formulations. He realized that, in prerevolutionary China, the peasants were the main revolutionary class and the "motor of the Chinese revolution" under the leadership of the proletariat. Mao made an important contribution to Marxist theory on the differentiation of the rural classes and the revolutionary potential of the poor peasantry dominated by the society.

Marxist scholars interested in the peasantry in Latin America have utilized the formulations of Marx, Engels, Lenin, and Mao to examine and interpret the conditions of the peasantry in the present Latin American societies. Historically, transitions and transformations take a dialectical path defined by the class struggle. Therefore, to understand the development of agrarian capitalism and the form it takes in rural Latin American conditions, the analysis 
must be done at the locus of class conflict and the reproduction of class relations.

For Jeffery Paige, the unit of analysis is the class relationship between "cultivators" and "noncultivators."31 A revolution is "on the agenda" when the upper-class "noncultivators" derive their income from land only and not from capital. Under these conditions the upper class is forced, by its structural position, to refuse concessions to the cultivators. Paige admits that whether peasants become revolutionary or not depends on the capacities of the peasants themselves, and that participation is based on the abilities of the lower-class cultivators.

Paige thus arrives at a different conclusion from those of James Scott and Eric Wolf. For Paige, the smallholding peasant, because he derives his livelihood from the land ownership, would be dominated by the upper class. Furthermore, the landholding peasants are mutually isolated and internally competitive, averse to taking risks, and strongly dependent upon the upper classes. Their response to market exploitation would take the form of a "reform commodity movement." Rather that as wage earners, propertyless laborers are identified by Paige as revolutionaries against landed upper classes, because they are more likely to exhibit group solidarity and deliberate support. 
Among the propertyless, he distinguishes between migratory labor service and sharecropping systems. The migrant laborers are seasonal wage labor, and when unemployed they return to their village, where many own a small plot of land. They lack organized political coherence. Their grievances tend to combine with those of other village strata and, according to Paige, to create "revolutionary nationalist movements." Only sharecroppers in Paige's view, because of their numbers, their homogeneity, and the nature of their contractual agreement with the landlord, are vulnerable to Communist ideology and powerful political parties. Paige contends that these affiliations are internally generated to form the basis of a socialist revolution. ${ }^{32}$

For the Marxists, the issues of transition to capitalism and of how "feudal" or "capitalist" were the relations of production in the countryside were the main contentions regarding the dependency approach, which has been used to analyze limited levels of development characteristic of countries that were incorporated late into the world system.

While most adherents of the dependency approach have looked at the "external factors" creating the condition of underdevelopment, Fernando Henrique Cardoso stressed the "internal factors" and especially the struggle between the classes. He aims at establishing a methodology for the analysis of concrete situations of dependency by emphasizing 
the importance of the historical processes that created the structures favoring dependent development.

The analytical theory dealing with the modes of production evolved from the criticism of dependency. A derivative of it is the approach of the articulation of modes of production, as an analytical tool that examines social transformations by focusing on class divisions within the agricultural sector. The patron-client relationship is the standard description of elite-mass relations and is an important aspect of emerging capitalist mode of production.

A mode of production incorporates specific historical combination of forces and relations of production. Each mode of production determines a particular mode of appropriation of surplus labor; that is, a surplus of the product of labor over and above the costs of the maintenance of labor. Actual societies are composed of more than one mode of production, all of which together create a socioeconomic formation, or a social formation. The major modes of production analyzed by Marx were the primitive community, the slave-based society, the feudal society based on serfdom, the bourgeois society based on capitalist mode of production, and the communist society. ${ }^{33}$

Current use of the concept of modes of production is related to social scientists' interest in the growth and spread of capitalism into the Third World. of special 
interest are the conditions under which the capitalist and precapitalist relations could coexist, and the conditions under which precapitalist tenurial relationships have been incorporated by the capitalist relations. The idea of "articulation" facilitates a more complex analysis of these conditions than the simple "combination" or "coexistence" of the modes of the production.

For Harold Wolpe, articulation is

the relationship between the reproduction of the capitalist economy on the one hand and the reproduction of the productive units organized according to precapitalist relations and forces of production on the other. ${ }^{34}$

Therefore, an articulated mode of production is

a complex structure doubly articulated by the productive forces connexion and the relations of production connexion. ${ }^{35}$

Pierre-Phillipe Rey, in Les Alliances de classes, defined and developed the concept of articulation of modes of production in order to illuminate political questions. Additionally, he distinguishes three stages of articulation as historical possibilities: 
1. an initial link in the sphere of exchange, where interaction with capitalism reinforces the precapitalist mode; 2 . capitalism "takes root" subordinating the precapitalist mode but still making use of it; 3. (not yet reached by the Third World) the total disappearance of the precapitalist mode, even in agriculture. ${ }^{36}$

According to Aidan Foster-Carter, in Rey's conceptualization, capitalism's logical final goal is the destruction of antecedent modes of production and relations of production to replace them with its own mode of production and relations of production. Therefore violence is needed, with exception in its articulation with feudalism. For Rey, articulation is a "process in time" that will essentially deal with the problematic of the transition to capitalism in the Third World countries. ${ }^{37}$ Rey envisioned the workings, in two stages, the transitional modes of production and the phase of neo-colonialism because of "capitalism's increasing ability to look after itself." 38

Patterns of class opposition and alliance directly reflect the degree of articulation of capitalist and precapitalist modes of production. The nature of patron and client relationships will change as the patterns of class alliances and opposition of a society change. 
In a recent study titled Rural Transformation and Peasant Political Orientations in Egypt and Turkey, Dani Rodrick writes

The tendency of most authors is to assume implicitly that the political outlook of the peasantry is simply a derivative of the ideology of the mobilizing elite. Based on this assumption the peasantry is endowed with a certain political momentum but denied direction. ${ }^{39}$

While Rodrick does not deny that the peasants are incapable of a "concerted political action," he argues that

the range of political action the peasantry is likely to participate, is determined by the rural processes rather than by elite preferences. Different processes of change will leave some peasant societies more conservatively oriented than others, and some more radically oriented. ${ }^{40}$

In the late nineteenth and early twentieth centuries, the pressures from outside, especially the spread of world market, set changes in motion. The presence of an elite with "local-orientation" maintained and strengthened patron-client relations. Hence, peasants whose orientation was thus shaped was most receptive to elite ideological inclinations parallel 
to their political inclinations. In the case of an elite with "nation-orientation," the countryside was characterized by absentee ownership and the development of a rural middle class. By comparison to the absentee owners, this middle class had quite limited economic resources; therefore the potential patronage was also restricted. The structural weakness of the patron-client ties in the countryside permitted the peasantry to align themselves with a different set of elites.

Finally, there is the approach suggested by Steve J. Stern. Regarding the study of peasant mobilization, he writes

The study of peasants and agrarian conflict is a field too sophisticated, diverse and politically charged to descent into a stale of uniformity. ${ }^{41}$

"Despite few notable dissents," says Stern, four views characterize the peasant studies. The first emphasizes the destructive impact of the expansion of the capitalist market economy. The second claims that the penetration of capitalism speeds up the process of internal differentiation of the peasant society into bourgeois farmers, and middle and landless peasants. In the third, agrarian conflict has an impact on the political history of the countries where the rural sector contains the majority populations. The fourth view holds that the peasants are defensive "reactors" to 
external changes, that is, that peasants as political actors have a parochial character.

Therefore Stern, pointing to the experience of the peasants in the Andean highlands, suggests a

rethinking of the assumptions and paradigms in four areas: the role of the peasants as continuous initiators in political relations; the selection of the appropriate time frames as units of analysis in the study of rebellion; the diversity of peasant consciousness and political horizons; and the significance of the ethnic factors in explaining "peasant" consciousness and revolt. ${ }^{42}$

Based on these guidelines, the idea of peasants as continuous initiators in political relations is of fundamental relevance. Because most peasant studies emphasize peasant political actions during times of crisis and relegate peasantry to the background of the political picture during normal times, those studies fail to understand peasant politics during those quiescent times, and thereby offer incomplete explanations to the causes of rebellion. Consequently, Stern points to an alternative approach to the study of peasant insurrection by looking at the

evolution of preexisting patterns of "resistant adaptation" that entailed innovative political 
engagement of the state by the peasants. In this perspective, the relevant question becomes not why a politically dormant and traditionalist peasant mass suddenly becomes insurrectionary, but rather why, at specific moments, ongoing peasant resistance and self-defense increasingly took the form of collective violence against established authority ${ }^{43}$

Hence, to analyze mobilization in the Andean region, one must look at the peasants' political activities as

continuously involved in the shaping of their societies, sometimes in a role of political initiators, not mere reactors, and often exerting an important limiting impact on their superiors and on "external" actors or systems. This perspective, in turn, serves as a prerequisite for understanding the causes and character of political unrest in the Andes. ${ }^{44}$

To achieve this approach is to view peasant protest as a short-term variant in a long-term process of resistance and accommodation to authority Stern suggests conceiving of it as 
an analysis that successfully incorporates multiple time scales into its vision of rebellion and its causes..$^{45}$

He also advises the use of "long-term frames of reference." In other words, the analysis of peasant protest should include the relevant period in the peasants' own historical memory, which Stern defines as "slice of peasant consciousness." This approach will aid in distinguishing between

genuinely new patterns of collective violence and grievance, and repetitions of historic cycles of resistance and accommodations that occasionally included some forms of collective violence. ${ }^{46}$

Studies of peasant protest in the Andean highlands should pay particular attention to the cultural history of the area under study, with respect to the other factors influencing peasant mobilization. It is impossible, though, to overlook the dependent state that is a characteristic of most of late- developing countries. Neo-colonialism in the rural areas creates special conditions that inhibit the development of capitalist mode of production and relations of production and maintain the precapitalist relations of production.

If peasant activism is not a recently emerging phenomenon, then what made it possible for the peasants to begin to make inroads? The general answer is that the 
society, rural and urban, was undergoing profound changes that created conditions more conducive for rural mobilization. 


\section{CHAPTER TWO}

\section{Part One}

\section{Rural Protest In Southern Peru: A Historical Review}

The Andean people in the highlands of southern Peru is relevant, have continuously engaged in forms of protest sometimes as political initiators, not only as reactors, and often exerting an effect on their local superiors and on external actors or structures. ${ }^{47}$

Peasants, by definition, interact with their landlords and state structures; and in the Andes this political inheritance includes centuries of experience that partly defines the issues in this study. Thus, for peasants the relevant time scales include not only the most recent changes, but centuries of struggle over the land. All of this experience defines the peasants' understanding of accurate rights and obligations in their relationship with the state.

\section{The Formative Era}

After the Incas became established in the area of Cuzco in the fifteenth century, they embarked on a systematic conquest throughout the Andes. ${ }^{48}$ In the process of building their empire, the Incas relocated and imposed the Quechua 
language on the people thus conquered to maintain strict supervision, exercise social control and exact tribute. By 1531, when the Spaniards began their conquest, the Inca empire was divided by contests for succession between the royal families of Cuzco and Quito.

The Spaniards were colonizers but lacked their own labor force, and consequently, they settled in areas where the indigenous population was concentrated. Their first goal was to find immediate subsistence while they collected booty; their second was to find labor to put to work on the local resources to guarantee permanent subsistence and produce wealth, preferably in exportable form. Once the pillage had run its course, means were found to incorporate the natives into the developing colonial society through the encomienda, and to re-settle through the reducciones, under the close supervision of a priest. ${ }^{49}$

Under the trusteeship system of the encomienda, uncontrolled use of native labor degenerated into ruthless exploitation. ${ }^{50}$ The policy of reducciones was ordered by royal decree after the defeat of Inca Manco Capac's rebellion. It is estimated that about 1.5 million Indians were involved in this project, and the reducciones are the origin of what later would be called comunidades..${ }^{51}$ From the perspective of the Spanish crown, the lands held by the ayllus were corporate holdings, claimed by the community as a whole. This policy 
was aimed at facilitating evangelization, but had more important effects in terms of economic and political control. During the colonial period, through direct levies, the crown extracted the surplus produced by the communities, and access to labor force was closely linked to political control. The relocation of the indigenous population contributed seriously to the disruption of agricultural activities and furthered epidemics. ${ }^{52}$

At the regional level, the administration of the crown's affairs was entrusted to a corregidor de indios. The corregidor was the bridge between the colonial bureaucracy and the Indian society. His position combined the roles of administrator, policeman, and judge. Furthermore, the Spaniards regarded some of the Indian nobility as senores naturales and therefore they became natural allies. In those cases, changes in the political and administrative structures affecting local affairs were relatively mild.

The Spanish crown instituted a system of indirect rule through Indian hereditary chiefs, or caciques, who supervised the allocation and collection of tribute. The caciques were made part of the lower level of colonial administration. With their position and prestige, they amassed large quantities of land and wealth. ${ }^{53}$ The only major protest of the formative era was led by Inca Manco Capac. It was a response to the local abuses of the corregidor, and an attempt to establish an 
independent neo-Inca state in the remote areas of the jungle. The rebellion was crushed in 1572. This put an end to the Spanish attempt to rule through the Indian nobility but the caciques were permitted to maintain their privileges and status, including exemption from tribute.

\section{The Mature Colonial Era}

By the last quarter of the eighteenth century the Bourbon monarchy was bankrupt and unstable. To enlarge the treasury, the crown attempted to exact as much as possible from the sale of offices and from through taxation. The holders of land grants acquired legal title and thus transformed the encomienda into directly owned and controlled land, or hacienda.

The population experienced a dramatic increase in absolute numbers of mestizos and Indians. In general, their degree of participation in the colonial economy exceeded the minimum needed to pay tribute and satisfy other taxes; consequently a process of differentiation began. For the poorer segments of the population, to avoid levies involved "passive resistance." Many villagers fled to the remote highlands or jungle, while others turned to seek protection from the new landowners under various kinds of informal patron-client agreements. The growing power of the landlord 
made it possible to offer some Indians protection from the mita service, the mines, or obrajes in exchange for becoming a colono. In addition to the mita, the corregidor developed repartos de mercancias as a means of extracting surplus from the rural population. For the goods assigned the peasants could be forced to pay in currency, services, or property.

Well over a hundred times during the years 1720 to 1790 the Indian population, sometimes accompanied or led by mestizos, rose up in violent defiance of the colonial authorities. Two rebellions stand out for their unique impact on the region: the 1742 rebellion led by Atahualpa and the 1781 uprising led by Tupac Amaru II, both mestizos. According to Steve Stern, the implications of the Atahualpa rebellion, are greater than heretofore recognized. In the ten years that it lasted, it strengthened the ties Atahualpa developed between the sierra and montana peoples and gave the rebellion its varied regional content. The effectiveness of the rebellion was attributable to the varied ethnic background of its participants. The success of the Adamarca invasion disrupted the delicate balance between the colonial power and the sympathizing serranos. Although the surrounding highlands did not become mobilized, there is evidence to suggest that Atahualpa's visions and exploits exerted considerable appeal, and that under different circumstances such sympathy might had led to more active support. ${ }^{54}$ 
Although at least 66 revolts took place during the decade 1770-1780, they fall in the general category of localized, reformist movements. During 1780 , the waves of localized unrest continued, ultimately erupting in the rebellion led by Jose Gabriel Condorcanqui, a descendant of the Incas who called himself Tupac Amaru II. This is how Fredrick Pike describes it:

Supported by vast Indian hordes, by many of the mestizos of the sierra, and in the beginning by a considerable number of creoles, Tupac Amaru uprising has been described by some as a genuine bid for Peruvian independence by others as a more limited endeavor to achieve Indian's social redemption within the colonial framework. ${ }^{55}$

The regions that joined the rebellion illustrate the critical role of the repartos de mercancias, as a link between the developing commercial bourgeoisie from Lima and the corregidor, of the increased tax and the commercial penetration. In colonial society, the Bourbon reforms threatened a variety of established interests and thereby sparked multiethnic dissidence. Yet one of the features of Tupac Amaru's rebellion is that, despite widespread resentment of the colonial government, only some rural regions participated in the general insurrection. In the second half 
of the eighteenth century, regional economic revival had increased the participation of the village peasants in commercial activities. The availability of work outside the community structure, specifically in mining and arrieraje, altered the traditional village patterns. ${ }^{56}$ The authority of the caciques declined in favor of the office of alcalde, with a concomitantly strong effect on village culture and community solidarity $\cdot{ }^{57}$

Changes in the economic and social structures were a result of changes in the system of land tenure. From 1750 on, the central highlands, the percentage of the land owned by mestizos and outsiders increased considerably. ${ }^{58}$ This period marked the beginning of the expansion of the hacienda at the expense of the neighboring communities.

The varied social background of the rebels and the militant visionary character of the movement frightened the entrepreneurial elite from Cuzco into an alignment with the colonial authorities. Tupac Amaru failed, like Atahualpa before him, to attract powerful caciques or to forge an enduring alliance between different ethnic groups. The lack of mobilization in the central highlands also indicates the extent of Spanish military build-up as a consequence of the 1742 uprising. Yet Tupac Amaru rebellion overcame the localized character of the earlier peasant uprisings. The conspiracies in the Mantaro Valley in 1780-81 and the wave of 
rebellions in Huarochirri in the northern highlands indicate the potential to spread the rebellion further, and the continuous state of animation that characterized the rural population. With the death of Tupac Amaru II, violence spread throughout the Andes.

The Formative State Era

The movement for independence in the La Plata region may have exacerbated an already difficult situation, in the southern Andean highlands, created by the threat of reinstitution of Indian tribute which the crown had suspended as a conciliatory gesture after the 1781 rebellion. Therefore, the 1814 rebellion represented a response to a local situation of abuse by Spanish administrators and little, direct relationship to the revolutionary philosophy voiced in Lima.

Mateo Garcia Pumacahua, who emerged as the leader of the rebellion, carefully tried to avoid the overtones of a racial war, and for a brief period he formed alliances between the creoles, mestizos, and Indians. In the words of Jorge Basadre who wrote on the events of 1814 , Pumacahua

stands in contrast to Tupac Amaru ... whose movement was one of collective vengeance, a rebellion against civilization, very just perhaps in its 
origins and motivations...but with a regressive orientation. It embodied pure agrarianism and indigenismo. On the other hand, there is the integral Peruvianness of Pumacahua, the man with the Indian blood who did not alienate himself with them from the creoles but identified himself with them...With close sympathy we can follow his uprising, desire its triumph, and lament its defeat, because the success of Pumacahua would have been the success of the fused Peru, neither separated from the creole as Tupac Amaru nor from the Indian as was the emancipation movement directed by Simon Bolivar. ${ }^{59}$

Although the rebels were defeated, sporadic guerrilla warfare continued throughout the period of the Wars of Independence. According to recent research, much of the support of the patriota armies against the royalists was extended by the mobilized peasant Indian communities. They supplied the revolutionary forces with food and, often, shelter. A large number of the arrieros served as spies. The presence in the rural area of a rich and successful mestizo group served to mediate the cause of independence with the peasants, and hence to draw upon an already mobilized force. The independence war was fought by the masses, but the republic did not change their status. The Indian tax was 
abolished by San Martin in 1821 and again by Bolivar in 1824, only to be reinstated in 1826 under the name of contribucion de indigenas, and coinciding with the Bolivarian laws of 1824 and 1825 that eliminated the legal status of communal holdings and provided that land be divided among its members. The purpose behind this move was to create among the peasants a need for money or products that could not be fulfilled within the confines of the community. Thus, once in debt, the peasant would sell his labor "voluntarily," seek part-time employment elsewhere, or sell his land. In reality, the process of capitalist penetration created the need for more land and labor. Therefore, the consequence of the rise of capitalism was the dispossession of the peasantry and, after their separation from the means of production, the land, their employment as wage-laborers. The process of capitalist penetration continued with the increase in the price of cattle, the attempted enclosure of grazing lands, and the pressuring of the communal holdings. As a result of the 1825 law, the land in reducciones was divided among family members and the titles held individually; consequently, communal land could now be bought and sold. ${ }^{60}$

The penetration of capitalism was not a homogeneous process: it varied according to local conditions and opportunities. Given the complexity of the Andean ecology, communities only a few miles apart could exhibit completely 
different patterns of commercial penetration. Local governments reflected these differences. Social relations were generally hierarchical, and few citizens were willing to challenge the authority of the governing elites.

Conflict between villages and the neighboring haciendas became inevitable, and by 1866 it had intensified with the introduction of a comprehensive package of taxes, known as contribucion personal, to be adjusted according to the income level. The enforcement of this law caused spontaneous protest throughout the southern highlands; it was especially violent in Huancane in the department of Puno. Although the contribucion personal was almost immediately abolished, the protest against president Manuel Prado escalated. The mobilized groups were caught between the political factions vying for power. In the process of maintaining order, violence was committed on both sides. The suspected rebellious communities were relocated to the montana.

By 1867, President Prado's political situation was unstable. Under these new conditions, Juan Bustamante politician and wealthy businessman from Puno decided to use his influence to mobilize the masses in favor of the president. He urged the peasants to address a letter of loyalty and support to the administration. Bustamante's liberal, constitutionalist principles, and his strong Christian faith were integrated into a vision of a divine 
order in which the president became the just king, the modern Manco Capac. This bore a powerful appeal in the highlands because it represented the utopian vision of redemption through the return of the Inca. This was not well received, especially considering that Bustamante was himself a mestizo. In 1867, Bustamante's last efforts to ensure the implementation of legislation favorable to the peasants failed, and within a week he had raised an army of over sixteen thousand, confirming both the strong bonds of loyalty he had forged in the district and the permanent state of alert among the communities in the sierra. He realized the need for a grassroots campaign of armed struggle to advance the goals of the peasants. Although the anti-Prado forces defeated the peasants, for months afterward a guerrilla campaign continued in spite of the military reprisals.

The persistence of the mobilization among the peasantry suggests that the rural masses may have had an agenda of their own, quite apart from the one pursued by Bustamante. Throughout the highlands, for the rest of the nineteenth century, widespread revolts continued against the consolidation moves of the hacendados and the local authorities. The European demand for alpaca wool, the increasing world market for minerals, and the demand for food from the developing Peruvian cities increased the value of the 
land and contributed to the establishment of a new wave of hacienda consolidation.

In 1903, new peasant uprisings took place in the highlands

Those of Huancane and Huanco were the most severe. In the latter site...the Indians tried to revive the Incan Empire and separate themselves from the country. (Even today, the Indians call Hunacho "Lima Hunacho" referring to the capital of their would-be-empire) $\cdot{ }^{61}$

The foregoing paragraph indicates that this was the same area that had rebelled under the leadership of Bustamante, and retained the devotion to the utopian vision of the lost Inca who would return to redeem his people.

Between 1915 and 1925, the peasant communities in the sierra rebelled against the waves of land enclosures. Although the military violently suppressed the rebellions, they had a profound effect on the government in Lima. In 1920 the newly installed Leguia administration supported by the Congress, promulgated a new constitution that reinstated the community as a legal entity. ${ }^{62}$

The struggle that "united" races and classes in the last years of the colonial rule was characterized by limited creole support, ambiguity about the political aims of the leaders. 
The rebellions appeared more as strong social protests to bring about change within the existing colonial system rather than to replace it. It may also be true that the failure of the sustained movements in the southern region of the country to secure independence was the result of existing divisions between the races. There is no denying, of course, that racial issues were associated with most of these rebellions into the twentieth century; but it would be a simplistic to consider only cultural divergence as the main cause, since it tends to overlook the social and economic issues that divide ethnic groups.

Such a conclusion would ignore the extent to which these uprisings were organized, collectively varied as it did their form. In the earlier periods some were more passive, others carried the implied threat of violence, and others erupted into actual violence. All were characterized by spontaneity, deliberate use of force, and local orientation, because their evolution was limited by the strength or weakness of community solidarity. John Fisher, in an analysis of the revolutionary movements in the late colonial period, suggests

One of the most significant themes to emerge in the work of the Peruvian historians in the last decades is the insistence that the late colonial period witnessed not an intensification of the conservatism and lethargy associated with the 
Viceroyalty of Peru, but a growing tide of revolutionary activity, supported by Peruvians of all races, in pursuit of the goal of national independence. ${ }^{63}$

Furthermore, he suggests that the importance of southern regionalism as a force "which united whites, Indians and mestizos in Cuzco" has been overlooked. It is apparent, according to Fisher, that the principal motives behind the dissatisfaction in southern Peru was Cuzco creoles' lack of effective economic and political power. It is of great importance that, between 1808 and 1811, the creoles from Lima remained quiescent while the creoles in the southern regions produced several movements of noticeable effect. The southern creoles were generally closer to the peasants both physically and socially, and nursed the same desire of restoring Cuzco to its former importance.

The romanticization of the Inca past was common to most southern mobilizations. Most far-reaching revolutionary goals in the peasant societies carry a religious charter that lies in millennial expectations. These expectations involve a belief in the imminence of a new order in which existing inequalities will be abolished. The religion and culture of peasants are syncretized local variants of larger system of thought and doctrine, and they contain the seed of an alternative universe. In a precapitalist society, where the 
link between the secular and the sacred has not been severed, this is one of the forms the revolutionary politics will take. Because of the significance attached to Cuzco by the creoles as a religious symbol in the millennial tradition, it might be probable that the creoles "used" the peasants for their own purposes and in the process the "new" elites affected the future direction of the peasant mobilization.

In the twentieth century, the goals of the protesters have diversified, but ultimately they have had something to do with land. Modernization produces changes that affect previous relations, and new actors may come to dominate the rural scene. As a result, the state may become increasingly hesitant to commit itself to support its former ally, the aristocracy, and therefore,

Peasant movements are more likely to occur in societies where traditional elites lost ground relative to newer elites through objective economic changes in the importance and structure of agriculture or objective political changes such as war. ${ }^{64}$ 


\section{Part Two}

\section{La Convencion Valley}

Only in 1788, close to fifty years after the movement (Atahualpa's rebellion) began, did the first tentative exploration penetrate into Chancamayo. For eighty years after that, all jungle outposts would be heavily fortified and militarized. ${ }^{65}$

\section{Area Description}

The valley of La Convencion is situated south of Chancamayo, 90 miles northwest of the city of Cuzco in the southern region of Peru.65 It extends 60 miles along the Urubamba river, beginning at its junction with the Aobamba and ending where it flows into the Apurimac. The territory belongs to a large zone of underdeveloped land on the eastern slopes of the Andes, and it ranges in altitude from 17,000 feet to about 1,600 feet. The terrain is highly irregular, with 82 percent of the land located on hillsides of 55 or more degrees angle; approximately 91.82 percent of the total surface, that is, $3,394,948.08$ hectares is unavailable for agriculture ${ }^{67}$ and that reduces the total cultivatable area to only 8.18 percent or $302,446.92$ hectares. ${ }^{68}$ 
The valley is quite narrow. The river forms several pockets where it widens to nearly a mile in width, and steep slopes drop down from the mountains. The geographical area involved in the peasant movement was approximately 17,650 square miles. It was settled in the late eighteenth century and cultivated mainly for cash crops. ${ }^{69}$ Relatively little is known of the pre-colonial settlements in the valley, although it is generally believed that Incas secured coca leaf from this area. The proximity to the Inca ruins of Machu Pichu also lends credibility to the idea of early Incan agriculture in the valley.

At the time of the conquest, the Machiguengas inhabited part of the valley. They occupied the lower end of the valley, near the present-day community of Quellouno. The earliest record of Spanish presence in the valley dates to 1541, when the area of the Huiro hacienda was granted by royal decree to the wife of the corregidor of the audiencia of Cuzco. The valley also served as an escape route for Inca Manco Capac and his followers as they fled from Cuzco to the remote area of Villcabamba. ${ }^{70}$ The defeat of Tupac Amaru I in 1572 signaled the complete submission of the Inca empire, and the Machiguenga tribe moved further upstream. ${ }^{71}$

From 1541 to the 1650 encomiendas were granted to the family members and friends of the conquistadores, religious orders, and few members of the Inca nobility, ${ }^{72}$ but the 
isolation that followed was a consequence of uprisings in the surrounding highlands. The outcome of Atahualpa's rebellion, in addition to driving missionaries and merchants out of the montana, kept the area from further exploration for more than 80 years. Hence, the valley did not develop for quite a while, it remained geographically inaccessible and the Spanish lacked interest in further colonization. The valley had no underground wealth, but a warm and humid climate allowed the cultivation of sugar cane and other products which were required with the opening of the highland mining economy. It was not until the end of the nineteenth century, however, that the sierra's mineral wealth began to be exploited.

In the late eighteenth century, the encomiendas evolved into haciendas, which became the traditional agrarian institution in the sierra. Although, the 1852 Civil Code, defined the status of the Indian as a Peruvian citizen with the same legal rights as other Peruvians and presumed that Indians could act in their own self interest

immediately following the promulgation of this code that the latifundian oligarchies began to be formed in Peru. ${ }^{73}$

The use of Law 1200 "on mountain lands" was instrumental in the formation of the latifundia, because the decree not only it encouraged concentration of land, it reinforced. ${ }^{74}$ 
Over a long period of time influential people received title to property in the ceja de montana as payment for political favors. Land was also merely acquired for speculation, in the hope that roads or railways would be built and the land could be sold for profit. ${ }^{75}$

On a national level, the period of civilian democratic rule, 1894-1914 was characterized by increased dependency and reduced governmental capability. Foreign involvement became the cornerstone of Peruvian survival. Foreign military missions were organizing and rebuilding the Peruvian military, foreign business and banking were increasingly taking advantage of the expanding opportunities in the private sector. Furthermore, world prices for the export products, especially sugar, cotton, wool, and minerals, were relatively high. The prevalent neopositivist ideology, justifying limited expansion of the state's role in order to strengthen rather than restrict the private sector, and the large debt accrued placed constraints on development.

Peru's external dependency increased during this period. The country's exports expanded fivefold between 1900 and 1919, and became more diversified. The configuration of foreign investments, likewise became diversified. New foreign investments in the export sector increased the price of land and mining concessions in the central highlands, which in turn caused many farmers to lose their lands and migrate to Lima or 
newly colonized territories. The coastal agricultural lands were purchased by foreign interests and changed from food production to production of sugar and cotton. Government income doubled between 1900 and 1909, then fluctuated within a narrow range until 1919, when it doubled again in the space of two years. ${ }^{76}$ But the state was unable to satisfy the increasing demands from a growing native entrepreneurial middle class and a radicalizing labor force.

Insufficient precedent for constitutional civilian rule, elections that still involved only a very small portion of the total population, and the effects of dependency on the newly articulate sectors brought about the end of the "civilian rule." The economic recovery under Guillermo Billinghurst and Manuel Pardo strengthened the power of the commercial bourgeoisie, to the detriment of the gamonales from the highlands. ${ }^{77}$ This process continued under Leguia's administration. In spite of it all, this phase witnessed the modern economic development of Peru, which, except for the mining enclaves in the central highlands, was concentrated on the coast.

The highlands remained largely rural and agricultural. Traditionally, this rural society it was dominated by large haciendas whose laborers served under semi-feudal conditions. Power rested in the control of the land, and like in all agrarian societies, control over land meant power over the 
masses. ${ }^{78}$ At the local level, the gamonal, whose power and wealth was in land, controlled the appointment of local government officials, and could prevent the enactment or enforcement of government actions he opposed, thereby undermining national government control. The effect on the comunidades was devastating. Labor tribute continued to be extracted. ${ }^{79}$ The communities lost much of their lands, and the lands that stayed under their control were often distant and poor in quality. In addition they had lost their legal right to exist as comunidades per se.

\section{The Lequia Legacy}

Between 1915 and 1925 the Indian comunidades of Cuzco and Puno rebelled many times, and the Tocroyoc rebellion represented the communards' response to the new wave of enclosures. By 1921, the Tocroyoc communards experienced some commercial success, in the export of wool. The community economy was transformed into a monetary economy and it took action to redress grievances such as obligatory labor duties in building roads and the supply of labor duty to the neighboring estates. The community petitioned the government to reclaim pasture rights lost to the estates. Furthermore, the communards claimed the right to hold their market, a right until then monopolized by the nearby market and its mestizo 
traders. Their leader, Domingo Huarto, was himself rich in money and livestock, and aspired to a commercial role similar to positions occupied by the mestizos but in the highland society of the time social mobility had restrictions. He represents the new entrepreneurial capitalist, the cholo, whose development was handicapped by the presence of precapitalist relations. Although the revolt was violently suppressed, it left a definite impact on the society. Eight similar episodes affected the department of Cuzco. ${ }^{80}$

Augusto B. Leguia came to power with widespread support, and the Oncenio, 1919-1930, marked a major effort to modernize Peru through the use of further foreign investments and loans. Rather than build a strong political base, Leguia tried to win patronage by providing schools, roads, public buildings, and water supplies.

The populist solution of the Leguia Oncenio was essentially the elite's response to the potential rather than actual threat of mass social mobilization pressures. Furthermore, this solution, designed as it was to protect elite privileges largely based on Peru's foreign trade, investment and loan structure, also protected and enhanced such external dependency relationships. ${ }^{81}$ 
In the wake of the peasant uprisings in the southern highlands, new legislation was passed, first regarding the Indian communities and second, the Ley Vial, or Law of Road Conscription. These laws created conditions ripe for rural mobilization. The law regarding the Indian population was in article 58 in the 1920, and declared the Government's obligation to protect the indigenous communities and to stabilize the relationship between the peasant communities and the haciendas. ${ }^{82}$ The law gave communities that had retained some traces of Indian culture the right to petition the government for official recognition as an indigenous communities. Such recognition re-established the principle of inalienable lands for members of community. It re-established the community as a "judicial entity," giving it certain rights in the legal system not otherwise accorded to villages. Most important, in cases of disputes with neighboring villages or large landowners, the community gained the right to appeal directly to the government's Division of Indian Affairs in Lima .

The law provided the peasant communities with an important weapon for holding back further encroachments by large landowners. Although the effects were primarily defensive, the law provided a base from which the campesinos from the altiplano were able to take offensive in a period of concentration of land ownership. In order to take that legal 
offensive, villages had to be recognized and inscribed by the government. In 1926 the Ministry of Labor recognized the first 59 communities in the nation, yet by mid-1960s less that one-half of the communities have been inscribed: 1,400 out of about $4,000 .{ }^{83}$.

There is justification for this lack of interest. Unfamiliarity with and the cost of legal procedures was a deterrent. After centuries of repression, the peasants did not trust the government and feared that recognition might be another way to be robbed of their land. And finally, it soon became evident that community land could not be favorably used to obtain credit. ${ }^{84}$ The most important law subsequent to the 1920 constitution was the Peruvian Indigenous Community Statute, which reaffirmed the prohibition against the sale of village lands to non-comuneros and offered the community some protection against the usurpation of its lands.

To modernize the country, Leguia's Ley Vial provided for the building of the roads that would connect the coast with the highlands. Peasants along the routes were required to provide labor in constructing roads and buildings for the local authorities. ${ }^{85}$ While this law was resented, the opening of the countryside provided contact with other villages, an essential ingredient for rural mobilization. In La Convencion Valley, the construction of the road and the railroad provided direct contact with the outside world, and 
stimulated internal growth, that is, the development of several small settlements along the construction sites. The laborers set up temporary campsites along the projected routes. In time, these campsites became more permanent nuclei of population when the temporary buildings were yielding to permanent adobe structures. ${ }^{86}$ Hacendados on whose estates these buildings were located charged a rental fee, the sigiaje, for the right to occupy the land. No purchases of land were involved, however, and all land was owned by the hacendados. In this fashion, the communities of Santa Teresa, Santa Maria, Chaullay, Huadquina, and Maranura emerged, as small commercial centers. In 1928 the railroad arrived to Machu Picchu, and in 1933 an extension road reached Quillabamba. ${ }^{87}$

Popular mobilization in Peru began with the labor movements on the coast and continued with labor struggle in the textile mills which climaxed with the passage of the eight-hour-day law. Well into the twentieth century, only a small percentage of Peru's population was politically active, and the vote was limited to literate citizens who owned property. ${ }^{88}$ It was during the labor struggle of the 1920, that Victor Raul Haya de la Torre first became prominent. He asserted that the Peruvian working class, whether rural or urban, lacked the class consciousness and experience needed to qualify for leadership; therefore he assigned this role to the 
middle-class. Although indigenismo was a major plank in the early platform of the Alianza Popular Revolucionaria Americana, the party's main concern remained Peru's middle sector: artisans, small landowners, professionals, and small capitalists, whose opportunities for economic development were constrained by the growing concentration of economic power with the foreign investors. ${ }^{89}$

The APRA advocated a powerful state that would guarantee to every citizen life, health, education, and moral well-being and to which individuals would be subordinated. From the beginning aprismo emphasized the plight of the middle sector. Although this was not new in the Peruvian ideology, at the time, under the Leguia regime, the middle sector was gaining numerically, politically and socially. Consequently, the middle class did not respond to the APRA's call to lead the proletariat in a revolution.

APRA's preoccupation with Peru's middle sector explains why Leguia became set on the party's eradication while he was relatively tolerant of Peruvian Communists. Despite -or precisely because of- the vagueness of its ideology, APRA managed to win over groups of urban workers and students whom it organized into unions that were its political base. According to Haya de la Torre, the developed countries were able to avoid violence in their internal development because of continuing integral evolution. In Peru, such evolution did 
not occur, and remnants of feudalism still existed alongside weak capitalist structures. Therefore, violence might be inevitable. In the national elections of 1931, the apristas refused to accept the results. In the process, an aprista shot president Luis Sanchez Cerro, and the violence that ensued, created a vendetta atmosphere between the Army and APRA that explains the armed forces' stubborn resistance to APRA's assumption of power and APRA's unwillingness to share the power.

The Communist party began to make inroads into the countryside in an effort to gain the support of the rural peasantry. Throughout the 1930s, the Communists in Peru called for the Indian communities to exercise their right to seize all privately held land that once belonged to them, as well the Indian right to govern themselves in Quechua and Aymara republics.90 The Peruvian Communist party was basically a reformist party. This was in line with Jose Carlos Mariategui's conviction that Communism in Peru should identify with the cause of the indigenous community.

Rural Population

For most of its history, La Convencion Valley has been underpopulated in relation to its economic potential. Migration into the valley began in the early twentieth 
century, but epidemics in the late nineteenth century and in 1932-35 killed thousands of people, with serious consequences for the development of the area. According to one source, it was estimated that eight to ten thousand people died of malaria and others fled the valley causing an acute shortage of labor. ${ }^{91}$

When the dangers of malaria were eliminated in the 1940s, the peasants from the sierra once again became interested in opportunities in the valley. The availability of land brought in a large number of migrants from the neighboring highlands, as evidenced by the increase in population from 27,243 in 1940 to 61,901 in the 1960 census. $^{92}$ Data from the first complete survey, in 1964, indicate that less than one-third of the campesinos living in the valley were born there, and that the average number of years in the valley for the arrendire was 28 and for the allegado20. Most of the migrants were born in the surrounding sierra provinces of Urubamba, Calca, Anta, Acomayo, and Apurimac, which were part of the region known as the Mancha India. Wesley Craig's study, found no evidence that any single province served as a source of migrant labor.

Hacienda Huayopata Chote has secured its labor from the Provinces of Canchis and Acomayo in the Department of Cuzco, the Potrero Hacienda has relied principally on migrants from the Department of Apurimac, with secondary sources being the 
provinces of Urubamba, Cuzco, Paruro and Anta in the Department of Cuzco. Sahuayaco shows heavy migration from Urubamba, Paucartambo, and Calca in the Department of Cuzco. ${ }^{93}$

According to Craig, the variations in the migration pattern might be the result of a particular engachador soliciting in the home areas of the migrants, and the already-settled migrants encouraging or contracting family or community members to come to the same hacienda. In the 1940s and 1950s, the influx of people to the valley continued. The increased migration of the campesinos, was given impetus by the rise in the world market price of coffee and severe drought on the altiplano. ${ }^{94}$ The international coffee boom of the 1950s period, referred to as the fiebre del cafe, had a profound impact on the local patterns of land tenure and rural society. ${ }^{95}$ Land was claimed by members of highland elites and highland peasants, and competition for access to good land near transportation became acute. Generally, it created a rush to clear and plant more land in coffee. Thus cash crops almost entirely replaced subsistence farming, with emphasis on export agricultural economy.

A simplistic analysis of the rural class structure in commercialized agriculture would consider a differentiation based on legal privileges, ethnicity, and technological sophistication, level of political activity and 
organization. ${ }^{96}$ Based on this framework, rural class systems diverge to the extent to which classes are set apart by legal privileges into landlords and peasants. The selection of these criteria will not suffice to describe certain qualitative aspects of the rural stratification in La Convencion at the time of mobilization, or the social changes the rural society assumed. Therefore, we must ponder the following issues: the relations with the means of production, the nature of the relations of production, and the mode of appropriation of surplus within the development of the capitalist agriculture.

Within a historically defined social formation, the social classes exist in permanent opposition: the exploiters and the exploited; those who own the means of production and those who do not; the group that appropriates the surplus and the group from whom the surplus is appropriated. In a rural society, the classes have to be defined by their relationship to the land, the means of production. This criterion in general determines ownership, nonownership or the degree of possession of the land. In a rural society like La Convencion, the use of this standard to set the classes apart will determine the social stratification between the owners of the means of production (the hacendados), the individuals in possession of the means of production (the arrendires, allegados, and sub-allegados), and the agricultural workers or 
wage-laborers. This is not satisfactory, since it does not explain the complexity of the rural society. Therefore, the social organization of the labor, that is, the relations of production as people established them among themselves during the process of production is an essential factor in the analysis of the rural society.

At the top of the structure in La Convencion Valley were the hacendados, with land very unequally divided among them. The landowners had been consolidating their power at national and regional levels since the late nineteenth century. On the hacienda, the land was worked by the arrendires, or agricultural workers. The arrendires, allegados, and sub-allegados possessed the means of production, and they had to perform labor for the landlord, in exchange for the use of the land. Nevertheless, the arrendires, represented the highest social category, from among the campesinos, because they used the labor services of the allegados and sub-allegados; and some of them may even have used wagelaborers.

To distinguish even further between the peasant who produces for the market and the one who does or not, we must look at the nature of accumulation of surplus. The accumulation of surplus may take the form of labor, of money or product. The hacendado may accumulate surplus based on labor and money. The arrendires, who possessed their parcela, 
appropriated surplus value depending on whether they had freed themselves of the labor service requirement by employing allegados. The appropriation and accumulation of capital thereby would be the result of labor service and of commercial activities.

The surplus originated from the labor service performed by the allegados, sub-allegados, and agricultural workers. Some of the arrendires, with smaller plots of land, continued to fulfill the labor-service demands; and in this case the hacendado appropriated the surplus generated. In the case of the allegados, if an allegado could subcontract to a sub-allegado, then the surplus was based only on the sub-allegado's work on the allegado's plot, because most allegados could not afford to employ wage labor. For the sub-allegado, who performed the labor service, his surplus labor was appropriated by the hacendado on the one hand or the arrendire, on the other. Sub-allegados possessed a small piece of land, but generally they were laborers. They transferred the surplus value to the hacendado, the arrendire, and the allegado. As for the segment of the permanent agricultural workers or tiapacoc, they sold their labor to the hacendado or arrendire for wages, similar to the seasonal agricultural worker or habilidado. The seasonal workers, might or might not own land in their community of origin. The final rung on the ladder was occupied by the rural merchant, 
who owned a factor of production that is, capital -and represented the new element in the rural setting.

Although the original separation in the Andean society was along racial lines, stratification in the twentieth century was on lines of economic social, and cultural differences. In the Cuzco area, class lines were maintained; , at the top there were the mestizos, who were hacendados, business and professional men, or government employees who controlled the machinery of administration in the rural areas. At the bottom were the Indians, the colonos on the estates, small farmers in communities, and unskilled laborers. In between the two extremes there was an economically and culturally important segment known as cholos, people who had ceased being Indians and aspired to gain the status of mestizos. Generally they had some schooling and were bilingual. They worked as small shopkeepers, or artisans, or farmed small to moderate-sized farms. Usually, if they held political offices in the community, their position would be at the bottom. In the 1930s and early 1940s, if a cholo segment was present, it was still minor and politically unimportant. After the mid-1940s, with the introduction of coffee, changes in transportation, and the development of provincial centers, this group gathered strength. Anibal Quijano suggested, 
these partially acculturated men (called cholos) were decisive actors in the political mobilization of Quechua communities in the Mancha India. Undoubtedly, village officials -the personero and the members of the junta communal- influenced their community's political behavior. They would be carefully listened to before the comuneros undertook a land invasion or joined a regional peasant federation. In short, the political orientations of the village's elite may well have been an independent determinant. ${ }^{97}$

No available information for La Convencion, however, reveals the way the whole peasant group was structured in relation to the ethnic distinction of the society. There are references to mestizos, Indians, and cholos in the writings of Wesley Craig, E. J. E. Hobsbawm, William Foote Whyte, and Giorgio Alberti; however, but clear ethnic implications lack clarity. It appears that in the process of leaving their native places, the migrating peasants adopted new social status; and the ensuing conflict between the hacendado and his tenants could have been partly based on the incongruity between the peasants' own view of themselves and the patron's idea. Yet it is impossible to deny that the core of the conflict was the contradiction between the customary structure of the tenure 
labor service that the landlord tried to uphold and the entrepreneurial freedom that the market economy required.

In the 1950s and early 1960s, poor agricultural performance generated economic and social pressures. The government's underlying problem was also one of the growing urban population, with rising living standards that could kept under control only with a change in accomplishments of the agricultural sector or if export performances remained strong enough to maintain the import of food supplies. Apart from the issue of food supply, the lagging performance of the agriculture would affect the supply of economic surplus for the rest of the economy. Past flexibility of the Peruvian economy had enabled successive governments to ignore the needs of the agricultural sector, despite willingness to consider an agrarian reform, failed to promote rural development and in some way it obstructed it. In 1956, the election of Manuel Prado as president marked the beginning of la convivencia, the "coexistence" of the once-radical APRA leaders and the conservatives, led by a traditional oligarchy. APRA did not hold any cabinet posts, but the party was legal, it won freedom for union activities and it received promises of support for the candidacy, of Raul Haya de la Torre in the following elections. President Prado appointed a commission, headed by Pedro Beltran, a leading conservative landowner, to study the question of agrarian reform. The commission was set 
up not in response to the peasants' request but as a response to the rapidly deteriorating national economic conditions and the high rate of rural migration to the cities. After deliberating for a few years, the commission produced two reports advocating, respectively, improvements in urban housing to accommodate migrants from the rural areas, and colonization of virgin lands east of the Andes as a long-term solution to the overpopulation of the highlands. The issue of agrarian reform, in the commission's view, should be avoided, and only the most inefficiently used large haciendas should be considered for expropriation with full compensation to the owners .

It would be easy to reject the Beltran commission as mere ploy, but its significance lies in the fact that it existed to pay lip-service to the idea of reform. It reflected changing political reality, a new consensus. The landlords in the traditional sector were becoming less powerful in national politics, while other contingents were becoming stronger and more organized. ${ }^{98}$ The Prado administration's policy on rural mobilization fluctuated between lack of understanding of the tenants in La Convencion Valley and repression of the comuneros in Pasco. ${ }^{99}$ Why the difference in the action taken against the peasants between one area and the other? It is generally believed that the Prado administration could have crushed militarily the movement in La Convencion, but decided 
it was not worth the expense. In La Convencion, many of the hacendados were old men or widows, managing the estates with little or no political influence; they therefore could not ask for extra government protection. Many of the properties were leased out or handled by administrators. Furthermore, the commission charged by the Prado government with investigating the situation in the valley favored change in land distribution. Finally, geographically in the valley of La Convencion, the mobilization could be confined to the isolated jungle area the government was less concerned about the threat it created the rest of the country.

In comparison, in the case of the Pasco comuneros in 1961, the powerful corporations that owned the latifundios of Pasco were able to demand strong government support peasant against land invasions. These events and the subsequent encounter with the military brought the land seizures to a halt. ${ }^{100}$ The Prado administration initiated a program called operacion desolajdo (operation eviction) as a coordinated military effort aimed at ousting peasants from the haciendas which were invaded by the comuneros, in November and December of 1960. The following March, several comuneros were killed, and thousands of others were removed, at the cost of some lives; but the offenders were stopped.

In 1962 , in response to increasing radicalization of workers and peasants in many parts of the country as well as 
uncertain national elections, the Peruvian military took power. It reacted promptly to the rural situation by instituting a limited land reform that granted coffee producers title to their plots without redistributing the land of the other haciendas. ${ }^{101}$ 


\section{CHAPTER THREE}

Part One

The Hacienda System

The Land

In the traditional rural economy, land is the main source of wealth. And income from land cannot be realized without labor. The land-tenure institutions in Peru were a product of the Spanish colonial system, which once established, served to perpetuate the traditional social structure. Ownership or control of the land in traditional agrarian systems carries with it political power: large landowner can make others do things for them, if necessary by force. The concentration of property in the hands of the few lies at the heart of the peasant problem in Peru. The same, relatively few people, have controlled the distribution of two resources, land and water.

Before the conquest, the highlands were inhabited by a dense agricultural population living in permanent communities. After the conquest, the mass of Indians was transformed into a peasantry, and the Spanish domination depended on their passive acceptance of the new order. The Spaniards assumed, in the beginning, that the land would remain largely in Indian ownership and they would be receivers of tribute. With the 
collapse of the encomienda system, the inadequacy of the tribute system combined with the demographic decline, and the Spanish colonizers began to take over land to develop new agricultural enterprises to support themselves. ${ }^{102}$

Once the ties with Spain were severed, the legal devices that until that time had granted a measure of protection to the Indian communities disappeared, and a period of land grabbing began that lead to the consolidation of the hacienda. Land became a commodity, and the best Indian lands were taken over by the large landlords or by the upward-moving "marginals. " 103

Eric Wolf and Sidney Mintz define the hacienda

an agricultural estate, operated by a dominant owner... and a dependent labor force, organized to supply a small-scale market by means of scarce capital, in which the factors of production are employed not only for capital accumulation but also to support the status aspirations of the owner. ${ }^{104}$

In Peru, the development of the hacienda system is characteristic of those regions where the presence of dense indigenous population encouraged early reliance on the encomienda system, and where the failure of the encomienda system was counteracted by the rise of the regional market economy depending on mining. The haciendas relied on a 
limited supply of local capital, which, in most cases, came from the church, interested in the purchase of fixed rents as a form of investment, local merchant groups, or small banks. The limited capital available was reflected in the level of technology, which requires small outlay of capital. The haciendas needed only enough capital to maintain themselves in a state of stability; they rarely expanded production, and they supplied a restricted market.

The most typical form of ownership of such estates was familial. Family ownership permitted the mobilization of wealth through kinship ties and personal contact. Thus, the traditional hacienda was basically two things: an estate that belonged to a recognized member of the privileged class, and a source of income to support the conspicuous consumption that demonstrated aristocratic status. Power and prestige as part of the status, were important components when lacking sufficient capital the hacendado, had to find capital and other means to assure his labor force.

As the value of the land gradually rose, the hacendado had powerful justification to hold onto it, even periods he did not want to cultivate. Doing so it avoided competition, and the monopolization of land helped to alleviate the labor problem. Therefore, the hacendado needed the excess land, less for agricultural purpose, than to deprive its laborers of potential alternatives to participation in hacienda process. 
The hacienda also, had control over enough land to grow its cash produce and to provide its workers with subsistence plots, and benefits. Such benefits were important for the relationship that existed on the hacienda, and, in most cases they took the place of wages. Very often,

a large hacienda or a group of haciendas will be surrounded by marginal land which they dominate indirectly rather than directly through control of the legal title. The inhabitants of these marginal zones will depend on the hacienda for cash wages and other perquisites, but often retain traditional cultural patterns in managing their own internal affairs. ${ }^{105}$

Since it lacked capital, the hacienda had to rely on cheap labor and on different devices to maintain it.

The province of La Convencion existed as an independent administrative unit until 1857. The origin of the hacienda system in the province dates to the seventeenth century. The first land grants were given as early as $1541 .^{106}$ From 1650 to 1669 , in the lower part of the valley, seventeen haciendas emerged in a zone dedicated to the cultivation of coca. Between 1720 and 1820 , five new titles were issued and many existing haciendas changed ownership. In 1767, when Carlos III expelled the Jesuit order from the colonies, land in the 
valley that belonged to them became state property and later was sold. After the Wars of Independence, the government continued to issue titles to land in the valley in exchange for favors, to public officials and to military personnel who distinguished themselves on the field.

By 1880 , all the land of the valley was in the hands of the hacendados. There were no small tenant farmers, there were no independent peasant communities, and no peasant owned land. The hacienda remained as the essential system of land tenure the valley until the 1890s.107

During the nineteenth and early twentieth centuries, the hold of the hacienda system was so strong that it withstood attempts by the Peruvian government to create independent communities by fiat. In 1887, a presidential decree ordered that areas be set aside within the various districts in the valley for district capitals. The hacendados were assured of financial reimbursement from the special tax levied on the production of coca. In 1893, another law demanded that boundaries be established, land bought, and district capitals be founded with the tax revenue from the coca leaf production. And again in 1902, a new tax of ten centavos on each 11.5 kilograms of cacao was mandated to be used for the expropriation of lands for the founding of district capitals.

Until the 1890s, when the government constructed a mule-path at the request of the landowners, La Convencion, was 
isolated from the rest of Peru. The power of the hacendados, although challenged by the presidential decrees, remained a united front.

The first split among the hacendados occurred in 1881, when one of the smaller landowners, Don Pio Concha donated one-third of his estate for the creation of an independent town that became the provincial capital of Quillabamba. This move was of great consequence for the development of the area: it set the stage for the emergence of a market center within the hacienda system. Until then, the hacendado dealt directly with Cuzco for supplies, labor contracting, and market. The peasant, whether a peon on the hacienda or a tenant farmer, received from the individual hacendado all the services he needed. Although it should be noted that as early as 1881 some merchants were living in the valley, they contracted exclusively with the hacendados, and another fifty years passed before additional communities began to develop independently of the haciendas.

The hacienda, in the valley, was composed of two structurally complementary sectors of production: the mejoras hacienda, or the demesne area, which covered the most fertile irrigated land in the valley and was farmed by tenants on behalf of the landlord; and the arriendos, or the non-demesne area, on which the individual tenant plots were located. In exchange for the use of land, the arrendires entered into a 
fixed-term contract with the hacendado. This system was a reminder of the feudal institution of seigneurie.

The land of a seigneurie is divided into two parts, each quite distinct but linked to the other by very close ties of interdependence. On one hand we have what amounts to a large home farm cultivated under the direction of the lord or his agents; ...which in French became domaine (and the in English is usually rendered demesne). On the other, we have a number of small or middle-sized holdings whose tenants owed the lord various customary dues and, still more important, helped in the cultivation of his demesne. Historians describe these holdings as 'tenures', a word from the legal vocabulary of the later Middle Ages. From the economic point of view this combination of large and small farming within a single unit is the essential characteristic of the seigneurie. ${ }^{108}$

The similarities end here. While the feudal manor was a self-sustaining unit that had little commerce with the outside world, the haciendas in La Convencion were primarily economic enterprises that provided crop, sold on the market. The land was worked through serf-like labor service, while for the hacienda different types of labor contracting were available. 
In medieval Europe, the lord of the manor owed allegiance to higher-ranking individuals. In La Convencion, important landlords, or gamonales, had almost absolute power within their lands and owed allegiance to no one.

In La Convencion the hillsides, the non-demesne part of the hacienda, where the tenant farmers' plots were located, were climatically better suited to coffee raising than the lands used by the landlords, located on the valley floor. Most of the demesne was planted with cacao, sugar cane, and tea, and landlords were disinclined to shift to new crops. Since colonial times the haciendas in La Convencion had produced coca and aguardiente, both products in demand at the mining centers at Potosi, Oruro and Huancavelica. The coca haciendas were involved in capitalist agriculture, since they were tied to the market. The use of slave labor gives an indication of the owners' economic interest in maximizing the use of the fertile land in the valley. Cocoa, introduced at the time of the independence wars or shortly thereafter, was produced for the manufacture of the chocolate in Cuzco. ${ }^{109}$ But the most important of the cash crops, grown under the permanent cultivation system became the coffee. Coffee was introduced, first in Dutch Guiana (Suriname), and it spread to Central America sometime between 1791 and 1808. Regarded as a needed export crop on which to base a viable economy, it became firmly established in the 1830s. ${ }^{110}$ 
In Peru, however, coffee and tea were introduced sometimes in the middle of the nineteenth century, and cultivation remained small scale and without specialization, as described in the following account.

For the middle of the nineteenth century, D. Mateo Paz Soldan, in Geografia del Peru, Lima, 1862, on page 399 reports a production per annum of: 25,000 arrobas of coca, 1,200 arrobas of aguardiente, 300 arrobas of cocoa, 100 arrobas of coffee, 250 arrobas of sugar. The annual Guia del Peru (1860) talks vaguely of cocoa, coca cotton and tobacco, but the 1872 edition no longer refers to these. In 1906 Carlos B. Cisneros, Resena Economica del Peru (Lima, 1906), mentions only coca and aguardiente; in 1914 Luis Valcarcel, 'La cuestion agraria en el Cuzco,' Rev. Univ., III (Cuzco, 1914), speaks of sugar, coca, coffee, cocoa and fruit, and mentions experiments with rubber and makes it clear that aguardiente and coca were overwhelmingly preponderant. It is clear from Kaeger (1901), that coffee was not yet seriously cultivated. ${ }^{111}$

By 1915, the export output from some of the haciendas increased: $\quad 60,000$ arrobas of coca, 20,000 quintals of aguardiente, 20,000 quintals of cocoa, 20,000 arrobas of 
coffee. The estate owners continued to produce the staples, and they were involved in commerce with the major cities: Lima, Juliaca, Arequipa, and Cuzco. ${ }^{112}$

The tenants were experimenting with coffee and some cocoa. But the peasants realized that they could get into coffee production without much investment and without taking any land away from other crops. Coffee was not yet cultivated under monoculture system, instead between rows of corn or other traditional crops, eliminating them only when the coffee trees reached bearing age. The harvesting and processing of coffee were relatively simple, labor intensive activities. Thus coffee lends itself well to smallholder cultivation. It is a colonizer's crop because it can grow on land that is only partially cleared and its high unit value makes transport costs bearable. The expansion and consolidation of the tenant holdings took place in the 1930s, when malaria destroyed a large number of the non-demesne labor force and the subsequent immigrants received more favorable tenancy agreements. By the late 1940s, many of the valley's tenants were supplementing their subsistence farming with the cultivation of coffee. Of all major agricultural export activities, coffee was the most reconcilable with small-scale land ownership and cultivation, since it did not require large production units, or farm sizes or heavy investment capital. 
The increase in the coffee production thus can be attributed to the tenant farmers rather than the hacendados' entrepreneurship. It is also directly associated with a corresponding rise in the world coffee prices. ${ }^{113}$

As the farmers were increasing coffee production, middlemen, or rescatistas, began to appear at the railroad centers, bypassing the landlords in offering credit to the farmers in exchange for marketing their coffee. Until then, the hacendado was the tenant farmer's only contact with the market. With the capital available to them, the tenants hoped to increase production but their contract with the hacendado proved to be in the way. Many tenant farmers decided to deal with the matter by hiring another peasant from the highlands to work for the hacendado in their place, or to work their land for them while they completed their obligations to the landlord.

To entice a villager from the highlands to come to the valley, the peasant farmer, or arrendire, would offer a parcela of his land with similar work obligations. The newcomer who entered an agreement with the arrendire was called an allegado. Additional hierarchies and increased economic differentiation developed when some of the allegados, following the same pattern, contracted with others to be their tenant farmers. The latter group was known as sub-allegados, habilidados, agregados or manipures. 
Although the Constitution of 1932 prohibited work without renumeration (Article 55), such forms of relationship continued in the valley as well as in other areas of the country. ${ }^{114}$

By the 1940s, the hacendados also began to switch to the more lucrative coffee market and started to pressure the tenants for more days of work during the harvesting and to reclaim the tenants' lands, by this time much improved parcels.

A study of land distribution before the rural mobilization of the 1950s, shows that nine large haciendas occupied 57.3 percent of the total cultivable land, or 320,417.49 hectares. Among these the hacienda Huadquina, which belonged to Alfredo Romainville, had a total of 152,480 hectares. During the mobilization, this estate was the site of the most militant peasant movement in the entire region of La Convencion and Lares. Furthermore the study indicates that there were 66 haciendas between 1,000 and 10,000 hectares, representing 36.7 percent or $207,420.81$ hectares. The 88 small haciendas controlled only 5.9 percent of the agricultural land, or $32,962.87$ hectares. The 38 properties no larger than 50 hectares, occupied not more than 0.1 percent of the surface or 719.46 hectares. Twenty-five of these units were worked by the proprietors, and twelve through tenancy. ${ }^{115}$ The existing land distribution in the valley 
indicates that the 176 hacendados with a total area of $478,381.60$ hectares represented about 85.5 percent of the total land area, with ownership of 1.6 percent of the productive units, while 11,059 tenants were in possession of the 98.2 percent of the agricultural units on an area of $80,340.60$ which represented about 14.4 percent of the available land. ${ }^{116}$

The first complete survey of the hacienda lands ever carried out in La Convencion Valley took place during 1964-1965. The data still show a vast under-utilization of the land, that less than one hundredth of the total surface was under cultivation, and that the tenants were occupying $43,553.6$ hectares under intense cultivation. The tenants were working nearly one-fifth of the total area of the haciendas. When analyzing this information we must remember that by this time, the valley has already gone through significant change, and that the hacendados most likely never worked directly more than one-fiftieth of their total area in any event. Consideration must be given also to the local topographical conditions.

In the late 1940s, in rural society of La Convencion (and Lares), the hacendados, exercised complete control over the lives of their 11,059 tenant farmers, and the tenancies were weakly established, and the tenant land was an unevenly distributed. Available data indicate that in certain 
districts within the region, the average size of the tenancy was much higher than in others. For example, in Santa Ana the average size was 4.9 hectares, in Maranura 3.3 hectares, in Huayopata 4.7 hectares, and in Vilcabamba 3.4 hectares. In Santa Teresa the average tenancy was 17.5 hectares, in Lares 8.0 hectares, in Occobamba 10.7 hectares, in Echarate 10.2 hectares and in Huadquina the average area possessed by the tenant farmers was 17.2 hectares. This data would indicate that the arrendire group with an average tenancy of 5.0 hectares per tenant farmer should had been more mobilized against the hacienda system than the arrendires that controlled plots of an average size of 17.2 hectares. Nevertheless, the tenant farmers in the districts where they possessed most of the land on average became more radicalized and their haciendas became the loci of the mobilizing activity. An explanation would be that the peasant mobilization in the district of Santa Ana, Maranura and Huayopata, took place under the auspices of the Communist party's reformist movement. The peasant activities in the districts of Santa Teresa, Lares were directed by Hugo Blanco and carried the imprint of the radicalism expressed by his Trotskyite faction. In short, Hugo Blanco's "Trotskyism" enabled the arrendires, simultaneously engaged in a twofold conflict, against the allegados and sub-allegados as well as the hacendados, to operate successfully on two fronts. By 
suppressing reference to the socio-economic differentiation arising from the capitalist development within the tenant-farmers group it permitted them to challenge the landlord class from within a heterogeneous anti-landlord front. Moreover, by expropriating the landlord class in the course of "dual power" it enabled the arrendires to reproduce and reinforce the politico-ideological images of egalitarianism with the allegados and sub-allegados..$^{117}$

The district of Echarate was originally under the apristas' influence and later fell under the control of the Communist Party. It seems inconsistent that it would be precisely the peasants who possessed the most land who composed the core of the most militant group, as an integral part of the general mobilization. Therefore, we must direct our attention to other interceding factors such as local political party ideology, party organization, and the existing patron-client relations on the respective haciendas.

\section{The Labor}

In the valley of La Convencion, the encomienda was not feasible, since the zone was practically unpopulated. Most of the members of the Indian tribes, from the higher elevations fled north to escape the work demands of the settlers; few were converted to slaves and put to work on the coca 
estates. ${ }^{118}$ The alternative source of labor was slaves from Africa. In the seventeenth century, the colonizers did use African slaves for a very limited period. The presence of relations of production based on slave labor, however, does not mean that the colonial economy was based on a primitive mode of production first, and then followed by a feudal mode of production. Instead, at that point of colonial development wage labor was unthinkable, since it meant the separation of the Indians from their means of production, the land -a development that historically had not yet occur. The presence of precapitalist relations of production within an economic system directed to produce for the market does not determine the nature of the mode of production.

As the hacienda became the valley's dominant institution, it was still difficult to exploit the land because of the scarcity of labor. The hacendados used engachadores, or agents, to contract wage laborers. Some of these agents were relatives or friends of the hacendados in the highlands, who helped with seasonal recruitment; others were professionals with contacts in various sierra communities. The recruiting was done during the Sunday market, which the engachadores found most favorable. This would often be the day the peasants were off from work and in need of cash. Once drafted, the peons had to sign a contract indicating the sum they received; then, the agent would give them a papelera, or 
receipt, showing the same amount. Usually, the peons would make their own way to the plantation. ${ }^{119}$ The labor was obtained from the "free" minifundia population as well as from the ranks of the "tied" hacienda peons. Another variant of the system of engache involved the forwarding of advance money to the relative of the recruited individual. Clearly, such additional cash advances would bind the person over a longer period of employment. In any case, the element of coercion was present. Although there was a wage-labor market, many of the recruited individuals were also owners of land; that is, the means of production.

The form of engache used in La Convencion differed from the classic form of labor recruiting used on the coast or the mining center in the central highlands. To co-opt the Indians to descend from the sierra, they were promised small plots of land (parcelas) on the hacienda, generally on the hillside in exchange for labor obligations to the hacendados. The length of the tenancy varied, but it was a fixed-term contract. In general, the lease seems to have been mainly between nine and ten years, which was needed if the tenant wanted to cultivate coffee, cacao, or tea. Tenancies that were paid for in labor services were a common occurrence in Peru, and they are called pongaje. In La Convencion valley, this term was not used instead, labor tenants were known as arrendires, and their tenancy as arriendo, which Hobsbawm indicated 
may suggest that serfdom in the province is not so much the child of a feudal tradition as the response by powerful landlords to an economic situation. ${ }^{120}$

The tenant had the obligation of working a certain number of days on the demesne, only part of what was known as condiciones; the payment for the land known as canon was required also. The condiciones varied according to each estate and the availability of the labor force, a point which I will discuss later.

Generally, the engache method of labor recruitment could be very costly because of the high rate of labor turnover. Therefore it tied up a significant volume of working capital in recruiting, with the risk of losing it to the recruiting agents.121 In La Convencion, there was much less expense involved; the tenants received the use of unused land and at their own expense improved it. Moreover, by the late 1930s with the increased migration into the valley, the hacendados no longer required the services of the engachadores.

In addition to the forms of securing labor described, Wesley Craig remarks on the use of habilitados,

direct contractual labor (these workers are called habilitados) for restricted periods of one to three 
months for the purposes of harvesting crops, planting and so forth. ${ }^{122}$

Eduardo Fioravanti also accounts for the presence of seasonal workers. He defines the habilitado as a temporary agricultural worker. He might be a smallholder in his community of origin, and sold his labor because he had to supplement his income. In the beginning, this system of labor contracting provided the necessary labor for a specific period of time for a stipulated wage. Because of population loss as a result of malaria outbreaks, the individual was often forced to stay on, especially if the landlord refused to pay him as required by the contract. Often he would be given the use of a parcel of land in payment for past services and future obligations. Hence, in practice the system of habilitado evolved into the pattern of engache. ${ }^{123}$

Finally, by the early 1950s the wage laborers, or tiapacoc, began to appear. This group of landless peasants was part of the migrant labor force that originated from the highlands. The labor market was thus transformed by population growth, proletarianization of the peasantry, and internal migration. 


\section{Patron-Client Relations}

The types of social structures found and the ways in which social control is distributed affect the capabilities and the character of states. In many respects these social structures derive from the unique culture, environment and history of each society. The social structures I am referring to are the patron-client systems, or clienteles,

which consist of sets dyadic relationships linked together for limited purposes over periods of time.... A dyadic relationship in its social science sense is a direct relationship involving some form of interaction between two individuals. ${ }^{124}$

Based on this definition, a dyadic relationship can be voluntary or obligatory for one or both parties. It can be diffuse or involve clearly specified obligations for one or both members in the relationship; it can be of varied duration: a lifetime or from generation to generation and it can exist between persons of equal or unequal socioeconomic status. The most important feature is that the relationship must connect two individuals by a direct personal tie. ${ }^{125}$ A patron-client system is made up of patron-client relationships that are 
a vertical form of dyadic alliance, i.e., an alliance between two persons of unequal status, power or resources, each of whom finds it useful to have as an ally someone superior or inferior to himself. The superior member of such an alliance is called a patron. The inferior member is called a client. ${ }^{126}$

The patron-client relationship usually supplies benefits that the latter cannot obtain by himself or can obtain only on rare occasions. Typically, the favors the patron does for the client are material, while those the client does for the patron consists of labor and services. Furthermore, the guarantees the client seeks from the patron are economic assistance and physical protection, while the patron seeks the complete personal subordination of the client. Generally, patrons maintain alliances with more than one client. Therefore, it is possible to organize a large part of a society in clienteles, often mutually exclusive; that is, no client with more than one patron. Clienteles are built hierarchically upon each other, so that several patrons, each with his own clients, are in turn the clients of a higher patron.

In the introduction, I stated that patron-client relationships appear as additions to institutions whose inadequacies they redress. The type of alliances that 
developed in the southern Andean region were a result of the superimposition of the Spanish element on the already existing societal arrangements as practiced by the indigenous population. The impact of the European expansion was quite uneven. Different lines of development were established by the encounter between the Spaniards and the Indians. The conquest did not totally disrupt old forms of social organization and control; in fact, penetration was limited to certain regions until well into the nineteenth century, when a true worldwide economy developed. ${ }^{127}$

The institution of encomienda established the basis on which the lord-peasant relationship developed in Spanish America. The indigenous population in what became Peru was entrusted to a encomendero, and converted to a dependent labor force used in the mining and agriculture. His obligation to protect, civilize and christianize the people entrusted to encomendero, gave him the right to received tribute and to make use of their personal services which suggests a pattern of labor tribute as a form of serfdom. The caciques belonged to a culture that emphasized hierarchy and position, and therefore they became the natural allies of the spaniards, whose rank and privileges corresponded with theirs. Within the colonial framework, the caciques were the vertical link between the state and Indian communities; they were essential for the flow of surplus from the communities to the state, 
through their access to Indian labor. At this level of association, custom was replaced by a legal grant and the caciques their privileges depended upon their relationship and services provided to the state. At the community level, though, customs prevailed and became unwittingly reinforced by the very nature of the Spanish practices. ${ }^{128}$

In La Convencion, owing to the lack of indigenous population, the encomienda was not successful and the institution of cacigazco was not practiced. The consolidation of the rural estate system, based on feudal relations of production articulating an owning landlord with land-possessing tenants, dates from the beginning of the twentieth century. Between 1900 and 1940 each hacienda was a semi-community unto itself. In the rural setting, the patron status was highly correlated with land ownership and the client status with tenancy, dependent on the patron's land for survival. The peasants became directly dependent for their subsistence on the landlord. Here is how sydel silverman described a traditional relationship between landlord and peasant:

A peasant might approach the landlord to ask a favor, perhaps a loan of money or help in some trouble with the law, or the landlord might offer his aid knowing there is a problem. If the favor was granted or accepted, further favors were likely 
to be asked or offered at some later time. The peasant would reciprocate -at a time and in a context different from that of the acceptance of the favor, in order to de-emphasize the material self-interest of the reciprocative action- by bringing the landlord especially choice offerings from the farm produce, or by sending some member of the peasant family to perform services in the landlord's home, by refraining from cheating the landlord, or merely by speaking well of him in public and professing devotion to him. ${ }^{129}$

In economic terms, the tenant owed his landlord two types of obligations: the payment of rent, ground rent as a recognition of the lord's proprietary right over the soil, and a recompense for the tenant's enjoyment of it and the performance of services. In La Convencion, the landlord-tenant relationship took the form of labor-rent, or condition, whereby each tenant was obliged to supply the hacendado with some form of labor-service, with the contractually stipulated amount of days, or turno, depending on the requirements of the landlord, the size of the property to be leased and the canon, or payments. The payments usually were excused for the first year, or during the period of the rozo, clearing of the virgin land and preparation for cultivation. However, after cultivation was established, the 
canon could be increased depending on the level of productivity.

The set of labor obligations included working the land of the landowner on an average of 10 to 14 days per month not necessarily consecutive on a fixed wage, which remained 0.40 soles per day from 1914 to the middle of 1950s. On occasion, the turno rose to 20 or 25 days, known as maquipura or extra, when the tenant and his family had to work for the landlord not for a customary wage but for payment agreed before each duty period. The palla was the obligation to supply at least one woman to pick coca leaves for each coca harvest, and it was paid at 0.20 soles a day until the middle of 1950s. This assignment sometimes included young boys. It extended to the coffee crop and sometimes the palladoras were required a few times a year.

The huata faena, or annual work, consisted of an obligation to work 10 to 15 days for food, drink, and possibly the gratificacion of one sol. The arrendire was also required to supply his dependents and peons to work on the hacienda at his expense, and that included food, chicha, and wages. The task of comisiones, comprised various kinds of duties when required at a wage of 0.50 soles a day. Road and maintenance work including the landlord's house was also an obligation in the condiciones. The hacendado also expected house servants, semaneros, to work unpaid for a fixed period of time. 
Additional transport duty, or fletas consechas, required to carry 66 kilograms for each animal on the tenants possession up to three times a year. The tenant was compelled to pay herbaje, for each head of livestock in his possession above a certain number, and to pay for timber in excess of his "necessities." He was required to plant certain crops and prohibited to plant others. ${ }^{130}$ He was under obligation to use goods produced on the hacienda, as well as sell his crop exclusively to or through the hacienda. ${ }^{131}$ The hacienda maintained its own stores from which the peasants were forced to purchase the few goods they could afford.

The landlord dealt with all legal matters for the peasants through his contacts in the provincial capital. No medical facilities existed in the valley save for the limited supplies that a hacendado would deem to offer. Few haciendas provided educational facilities for the benefit of the peasant children. In effect, the hacendado prevented education for the peasants because it would make "agitators out of workers." Control on the estates was imposed from above. Discipline was maintained through implied violence, actual violence or by the threat of eviction. Corporal punishment was still occasionally found on some haciendas.

In many areas of Peru it was common to find that peasants living on the haciendas were prohibited from receiving nonresident visitors or visiting without the authorization of 
the management. Association among the peasants was often prohibited, and generally not encouraged. On some estates in the valley, the peasants were forbidden to wear shoes or to stand in the presence of the landlord, who also still imposed his seigneurial rights on the women on his estate. Moreover, the peasants were not allowed to address the landlord in Spanish and attempts were made to restrict all communication to Quechua language.

The tenant farmers in such a society had very limited contact with anyone outside the particular hacienda on which they lived and worked, and were dependent upon the hacendado for contact with the outside for selling and transportation of products from their plots. Hence, the flow of supplies and services was from individual hacendado in the valley to the commercial and political centers outside the valley. The hacendados effectuated the appropriation of surplus value through the control of the market outlet, which they secured by monopoly over the land and by the below-market cost of the demesne production protected by the labor-rent mechanism. The tenant farmer was compelled to market his product through the agency of the landlord and he received 50 to 60 percent of the product's market value in return. Coffee from the hacienda Maranura and produce the haciendas Santa Rosa, Huadquina, and Chaupimayo were marketed in this way. The cash return for 
labor services was between one-fifth and one-quarter of the market wage. ${ }^{132}$

The persistence of the precapitalist relations of production, as exemplified by the tenancy system in the valley, suggests that they were beneficial for the landlords, and the use of wage-labor may have created economic difficulties for them by comparison. From the hacendados' point of view, tenancy presented advantages over wage-labor in return of labor, investments in technology on the hacienda, and the guarantee of labor. The dominant pattern of production relations between landowners and arrendires was combined with other types. The allegados, in return for their work that is, to substitute for a tenant farmer on the hacienda would get a small plot from the arrendire with whom they entered the contractual agreement. Under this system the allegado was obliged to work for the original tenant for a specified number of days a week, just as the arrendire did for the hacendado. Hence, within the hacienda system, patterns of patronage could in effect operate at different levels in the structure. In addition to allegados, sub-allegados might be recruited to provide the same services as the allegados did for the resident arrendires.

The mode of production on the hacienda tied the tenant farmer to the hacendado, who owned and controlled the means of production, in a precapitalist relations of production. 
The hacienda mode of production was not geared to subsistence production, for the hacendado was primarily interested in exporting to the local and external markets, and many haciendas were linked to nearby mining centers through the provision of food and coca. Some more successful haciendas had both labor service provided by the tenant farmers and wage laborers. Thus, each hacienda represented a combination of social relations based on different modes of production: a tenant system based on a precapitalist mode of production articulated with a capitalist mode of production. At the level of the tenant farmers, the precapitalist mode of production was combined in a similarly complex pattern of relations with the other mode of production.

The preservation of precapitalist modes of production articulated with the emerging capitalist mode of production suggests a maximum feasibility for appropriation of surplus. The contradiction between the dual modes of appropriation and the requirement for capitalist expansion emerged in the period between 1940 and 1947 .

The increase in the global demand for coffee and its concomitant price increase, and the expanded demand for staple products, and the expansion of the internal and external markets in conjunction with the decrease in the costs of production (as an outcome of the expansion of roads and 
railroads) resulted in increased profitability for the hacendados and arrendires.

These factors exposed the constraints to capitalist production intrinsic in the feudal relations articulating hacendado and arrendire. The obstacles to further expansion were the market monopoly exercised by the landlord and the labor-service mechanism. The market monopoly prevented the increase in the rate of profit, and its collapse was caused by the presence of merchant capital, which contributed to the rapid increase in the coffee output by the coffee-growing arrendires. The second constraint, the labor-rent mechanism, the basis of the condiciones, is a more complex issue. The payment of rent in labor-service required the arrendires to contract hired labor or alternatively to contract a subtenant, to whom they in turn leased a small portion of their his holding.

The use by the arrendires of two different forms of labor is an indication of a structural differentiation induced by the capitalist mode of production. The cash advanced by merchants for coffee allowed some of the arrendires to hire wage labor and eventually to increase their cultivated land. Unlike them, other arrendires had to sublet land in order to find an individual to substitute for them on the demesne. This resulted in the introduction of a new relation of 
production intervening in the landlord-tenant articulation, and the a further stratification within the peasant group.

In essence, the immediate roots of the peasant mobilization may be found in the systemic attempt of the hacendados to reimpose the system of serf labor, and their later attempt to take over the lands cultivated by the tenant farmers . 


\section{CHAPTER FOUR}

\section{The Protests}

\section{The First Stage}

By the late $1940 \mathrm{~s}$, the labor structure of La Convencion consisted of three levels: arrendires, allegados, and sub-allegados. ${ }^{133}$ To defend themselves from the demands of the hacendados and the insecurities of the tenancy system, they joined forces and set up the first organizations. The first union was formed in 1947 at Maramura, a hacienda of 2,049 hectares, with 100 arrendire each working 5.3 hectares and 200 allegados with an average of 1.2 hectares. ${ }^{134}$ The secretary-general was an arrendire, formerly a teacher and a businessman.

The demands of the union members were as follow:

1. An eight hour workday.

2. The right to sell directly, bypassing the hacendado

3. Payment in cash rather than script or credits at the company store.

4. Exemption of women from heavy farm work.

5. Construction of a school.135

To press their demands, same peasants stopped working on the hacienda after eight hours. In 1948, the united 
arrendires, allegados, and sub-allegados gained the eight-hour work day. In the same year the hacendados allowed the tenants the right to sell their produce outside the village, to the market. The following year the peasants were allowed to build a school. The union was then dissolved as a consequence of government repression, only to rise again in 1957.

The second union was recognized in 1951 on hacienda Mandor, involved primarily in coca production. The tenants on this hacienda had been allowed to sell their produce on the market but had been denied the right to organize. This union began to file protests with the Ministry of Labor in Cuzco. In 1952, the Odria government officially recognized it. Apparently the administration, although it did not change its position on unions, saw advantage in favoring an organization led by Communists, over the APRA-led union. But until 1957, after the fall of the Odria government, no new unions would be formed. 136

In late 1954 and early 1955, the FTC established the Secretariat for Peasant Affairs, to provide assistance with grievances and further support in organizing unions on other haciendas. In the following years the peasants, through their attorneys and contacts in Cuzco, became acquainted with the Federacion de Trabajadores de Cuzco, a militant Communist labor union. ${ }^{137}$ The Peruvian Communist party, had already penetrated the countryside, and by the time of the outbreak of 
the mobilization it was familiar with the conditions in the area and were able to help the organizing efforts of the campesinos. According to the valley labor leader,

the FTC was the only group to show any interest in our organizing efforts and who offered to help us. ${ }^{138}$

The help consisted of legal assistance by various lawyers who moved into the valley and became recognized as legal advisors to the peasant federation. In addition, they advised the peasants on organizational procedures and strategy. The FTC also sent labor leaders, who were of Indian origin and were easily accepted among the union members. The leaders of the peasant sindicatos in the valley were local men, with but one major exception, elected to positions of leadership from within their own hacienda and not brought in from outside. ${ }^{139}$ Likewise, the federation of peasant unions was composed of legitimate representatives from the different hacienda peasant unions .

By 1958, peasant sindicatos on eight haciendas in La Convencion and the sindicatos from Lares joined together on a regional basis to form a valley federation, Federacion de Sindicatos Campesinales de la Convencion y Lares. In addition to this principal peasant union, a small number of peasant sindicatos sponsored by APRA and led by a local arrendire, 
organized into FENCAP unions. APRA, while strong in the northern coastal area of Peru, had limited influence in the Cuzco area.

Analyzing the early stages of the mobilization, Wesley Craig found that both arrendires and allegados were represented. The peasant representatives had been migrants to the area within five to fifteen years prior to their involvement. The elected leadership was generally the more acculturated peasants of the area, who could speak Spanish in addition to the native Quechua. Based on his findings, Craig concluded

Despite the outside advisory roles of the lawyers and various FTC representatives to the valley, the major part of the organization and development, particularly during the early phase from 1952 to 1960, was primarily an autonomous movement within the valley and constituted an unusual Latin American phenomenon of a rural labor union organizing itself from the bottom up rather than being organized and directed from outside. ${ }^{140}$

The initial demands made were moderate. Total abolition of labor obligations was not sought, nor was land reform demanded. Some of the initial leaders were evangelicos, or Protestants, but the total percentage was too small to make 
the difference attributed to them, and moreover, they did not maintain leadership positions. ${ }^{141}$

\section{The Second Stage}

The rise in the momentum of the second stage in the mobilization corresponds with the decline of coffee prices from 1954 to $1961 .{ }^{142}$ By the mid-1950s, the tenant farmers had gained an important stake in the economy of the valley. A government report for 1957 estimated per capita production in La Convencion at 1,357 soles per year, compared to 260 soles per year the annual average for Cuzco. According to the report, the problem was not a lack of resources but a highly unequal distribution of these resources

Nine owners ( 4.3 percent of the total) each held lands o over 10,000 hectares. More than 57 percent of the territory was in their hands. One hacendado, Alfredo Romainville, owned 152,480 hectares. Sixty-six owners held land of 1,000 and 10,000 hectares, while eighty-eight owners held lands of from 50 to 10,000 hectares and twenty-five owners had plots small enough that they could work them themselves. ${ }^{143}$ 
In 1961, at the insistence of the hacendados, an investigator from the Ministry of Labor was sent to the valley to study the situation and make recommendations. The investigator found that the development of the social infrastructure lagged behind the economic growth. The peasants showed symptoms of nutritional deficiencies, 85 percent of them lived in unsanitary conditions, less than 40 percent of the potential pupils were enrolled in primary schools and that high school education was available only to those who lived in the provincial capital of Quillabamba. When the findings were presented to the commission in Lima, it suggested that the condiciones as a form of contractual labor arrangement should be abolished. Because the government was not ready to act on this recommendation, the report was shelved. In La Convencion, the political leverage of the hacendados was waning, but the region was a not political asset. It is important to remember that during the Odria administration, most union activity was illegal, and only with the installation of President Prado did all political activities become legalized and votes become important.

With the federation as a bargaining agent, the tenant farmers escalated their demands. This time, the peasants sought the elimination of the obligations by substituting them for rent paid in cash, and long-termed land leases. The federation also demanded that tenants be permitted to sell 
their coffee directly to commercial markets, without any interference form the hacendado. Although initially lawyers from Cuzco, of different political affiliations, helped in representing the peasants in their demands, by this later stage many had moved into the valley and had become the recognized legal advisors, exerting direct leverage on the peasants' decision-making processes.

In the area of Huadquina, on the haciendas Santa Rosa and Chaupimayo, the mobilization became more radicalized than elsewhere. ${ }^{144}$ When peasant union was formed as a response to the situation, a ministerial resolution prohibited the arrendires and allegados from forming syndicates, and made it possible for the authorities, at least temporarily, to jail the leaders and declare the union illegal. ${ }^{145}$

The year 1960 was a turning point in the development of rural mobilization of La Convencion: 130 unions belonged to the peasant federation, and its membership included over 11,000 campesinos and 6,000 agricultural workers in the valley. The mobilization once restricted to the southern part of La Convencion was beginning to assume the proportions of a real movement. ${ }^{146}$ The natural momentum developed by the original peasant unions now began to realize collective strength and show solidarity. One example was the "sympathy strike" that took place in June-July 1960, in which the peasant unions from various haciendas stopped work for their 
hacendados because peasants on one hacienda were mistreated. Representatives of the Peasant Federation of Cuzco were sent to organize the colonos in the provinces of Paucartambo and Calca. The working conditions on hacienda Chawaytiri, in the province of Calca, during the potato harvest of 1960 accelerated the process of union organization and the ensuing plans for a strike. After beginning the strike the colonos set up their organization and began electing officials from their own communities. In 1962, they submitted a written complaint to Ministry of Labor and Indian Affairs in Cuzco. The strike continued until June of that year. The unionization on Chawaytiri, brought immediate "symbolic changes in their interpersonal relationships." Although, the colonos signed their contract with the hacendados with the aid of the Peasant Federation of Cuzco, the following months saw them shift their efforts from getting contract enforcement to securing claims for land ownership. The first claim for the right to purchase land on hacienda Chawaytiri was lodged in December 1962; this phenomenon was not unique, it was occurring elsewhere in the department. The power of the mestizo landholding elite was declining and a new leadership was emerging from among the schoolteachers and businessmen. This group originated from the mestizos and cholos in the area, and studied at the University in Cuzco during the period when the government was emphasizing the role of the teacher as 
an agent of change in the community. ${ }^{147}$ of equal importance was the process of political radicalization that swept the country from the late 1950s and through the 1960s. University students held meetings and demonstrated in favor of agrarian reform and peasant mobilization. Many became involved with the Peasant Federation of Cuzco.

The emergence of Hugo Blanco as a leader of a union from hacienda Chaupimayo increased the militancy of the peasants in the valley. A native of Cuzco, an agronomist educated in Argentina, Blanco was fluent in Quechua and Spanish. He began to work as an allegado for an arrendire, and because of his leadership qualities was soon elected to be the representative of the hacienda's union to the federation.

A certain revolutionary feeling existed on Chaupimayo: union meetings were held daily and alcoholic drinks were forbidden. For better protection against the landlords, the peasants organized themselves in hamlets. Another way to enhance the strength of the peasant group consciousness and the collective action were mass meetings in Quillabamba and Cuzco. A school was built on the hacienda, and teachers were brought in from Cuzco. The teachers contracted to work for the schools in the valley, an example set by Chaupimayo, developed a program that explained the basis of class struggle, various agricultural issues, and developments in farming technology. ${ }^{148}$ Chaupimayo became the base at which 
several self-defense training courses were given, and at a later date the locus for the development of militia groups to protect themselves the peasant's families against possible violent acts committed by the hacendados. These para-military organizations were used by the Blanco in his confrontation to gain political power. The peasants in different unions participated in general community improvement works such as road construction, irrigation, bridges, public buildings, and medical offices without any help from the government.

In 1961, the Federacion Departmental de Campesinos y Comunidades del Cuzco was formed with 214 sections. Blanco and his followers sought support for more radical tactics such as occupation of hacienda land and violence. Their slogan became Tierra o Muerte. Early in 1962, the federation decided to call for a general boycott against the hacendados. Based on the decision of the federation, no arrendire, allegado, or sub-allegado was to work for the landlords in the valley, and no payment for the rental of the parcels was to be paid.

On April 24, 1962, the Prado government issued a decree that abolished the condiciones and specified that tenant farmers must pay rent to the hacendados for the continued use of the parcelas. The peasants refused to pay rent. In May 1962, with considerable support, Blanco was elected secretary-general of the federation. However, the elections 
laid bare the differences between the groups in the peasant movement: the reformists, the older FTC-inspired leaders, and the radical supporters of Hugo Blanco.

The unions controlled by the arrendires, under the influence of the FTC, corroborated the Prado government's position regarding the situation in the valley and opted for the maintenance of the status quo. The arrendires, once they received ownership of the land they possessed (some of them as many as four parcelas), changed into the new rural bourgeoisie. In control of the unions, the arrendires, once the vanguard of the rural mobilization, were able to dominate and repress the peasant movement. Basically the arrendires, faced with new opportunities, initiated the confrontation against the hacendados and then transformed themselves into the dominant and conservative class of the new arrangements in the countryside.

With the capitalist relations of production clearly established between the new class of proprietors and the rural proletariat, obligations of wage labor replaced those of labor service. The allegados and sub-allegados, as part of the smaller rural bourgeoisie, and the rural proletariat were not satisfied with developments resulting from the April decree, which favored the original tenant farmers; they wanted radical reform. The unions they belonged to were led by Hugo Blanco, and they sustained the peasant mobilization after April 1962. 
Therefore, by 1962 a pattern of mobilization had emerged: first, the organization of the union, the bargaining agent for its members, and then the struggle for better contractual agreements with the hacendado. The final stage was represented by the struggle for land ownership.

National elections on June 10, 1962, failed to give a majority to any of the three major candidates. The decision passed to Congress. On July 18 the military annulled the elections and took power to prevent its traditional enemy, APRA leader Raul Haya de la Torre, from being chosen to lead a coalition. By this time, occupation of the hacienda lands, urged by Blanco, had been carried out in a coordinated fashion. The military junta recognized the de facto control of the land by the tenant farmers and in a decree issued same year, indicated that the peasants could keep the parcels but that in order to secure title they had to pay the government which would handle the hacendados. This act brought the complete separation of the campesinos from the hacendados. ${ }^{149}$

\section{Changed Relations}

The general boycott declared against all hacendados in the valley, whereby no arrendire, allegado, or sub-allegado was to work for any landlord in the valley nor was any payment to be made for rental of parcels, removed the traditional 
labor supply. The cost of employing habilitados was too high. The lack of labor was increased by the government road construction projects in the highlands, which paid higher wages than did the hacendados. The drop in production on the hacienda lands can be correlated with the increasingly dominant capitalist relations of production. The hacendados who produced coca and coffee were affected the most. It will be recalled that these hacendados relied on the labor services of the arrendires and their families during the harvest time. The entire coca production was labor intensive, not only during the harvesting. In the absence of a cheap labor supply, the coca became less profitable, compounded by falling prices during the period 1963-65. The hacendados who switched to coffee production showed a marked decrease in production.

Many hacendados demonstrated little initiative in handling the labor problem. A great majority passively waited for the representatives from the government agencies dealing with the subdivision of the lands, as a way of getting some money so that they could leave the valley. A contributing factor to the inability to change was the advanced age of many of the hacendados, plus their children's apparent lack of interest in hacienda matters. Few hacendados were able to make the adjustment to the labor changes. The ones that survived, owned haciendas where even before the mobilization began there was a higher rate of capital investment in the 
form of wage-labor and machinery. Sugar cane and cocoa were the crops that required large-scale labor input; therefore they were also adversely affected by the labor shortage unless the hacendados decided on increased mechanization. ${ }^{150}$ In effect, the capitalist mode of production, in articulation with other modes of production, became dominant. The legal abrogation of the condiciones, that is, the labor-rent mechanism, ended the use of precapitalist relations of production. ${ }^{151}$

From its inception the rural mobilization was organized and led by the wealthier segment of the rural population, the arrendires. The arrendires, when faced with the likelihood of losing their land, their source of income, reacted by organizing around the collective interest. Their dominant economic position did not correspond to the position of political subordination to the landlord. As the most advanced segment in the rural population involved in the process of capital accumulation, the tenant farmers were at same time the group that provided the largest amount labor service on the demesne. However, their political demands reflected the collective economic interests of the organized group: the abolition of monopoly over the sale of the tenant's produce, the eight-hour working day on the demesne, the abolition of the labor-rent service mechanism, cash payment for extra-labor performances, etc. The peasant union, from the beginning, 
represented the instrument used by the arrendires to counteract the situation of insecurity maintained by the landlord regarding the use of land. ${ }^{152}$

Thus, the tenant farmers became the vanguard of the peasant organization, and created and supported the unions as a function of their own class interests. The alliance between the arrendires, allegados, and sub-allegados created a novel situation for the landlord; a united front with a leadership from within, from the cholo segment of the population. ${ }^{153}$ In political terms, the struggle involved the mobilization of a multi-class alliance, composed of tenants, sub-tenants, and small merchants, against the hacendados. At this time, the unions become the only representatives of the peasant group, and they established direct relations with the judicial and administrative government offices as well as the departmental ministries in Cuzco, to which they presented their complains and demands. The union actions were within the legal parameters; their objectives included protection for the tenant farmers against eviction from their plots and demand for immediate improvements in the condition of the peasantry was of interest to the majority of their members.

For the arrendires, the new rural bourgeoisie, the ownership of the land was the issue -one which in fact questioned the entire hacienda system. The arrendires directed the struggle for the ownership of the land to end all 
insecurities involved in the former relations of production. The allegados and sub-allegados, who participated in the mobilization, eventually received some compensation; but it was only the arrendire segment that developed into a class for itself, with a class consciousness and a goal. The arrendire was the only segment whose actions reflected a degree of group consciousness because their interests received full economic articulation. 


\section{CONCLUSION}

Peasant mobilization is rooted in long-term changes in the structures of society, the economy, and politics. The historical survey of rural protest in the southern Peruvian highlands, indicates that in the formative and mature colonial periods, Indian ethnicity played a significant role, and the peasants rallied around community-based solidarity. Despite the limited nature of creole support, these movements appeared as strong social protests within the system rather than replacing it. The analysis of rural protests in the twentieth century shows that modernization produced changes affecting all facets of previous relations and creating conditions favorable to the organized protests.

Although rural protest was historically endemic to the Andean region, intense agrarian mobilization had rarely resulted in organized protest. And then, between 1958 and 1965, three massive peasant protests swept through the central and southern highlands. In the Valley of La Convencion, an area where turbulence was virtually unknown, discontented peasants on dozens of coffee haciendas mobilized against their landlords in a successfully organized rural protest. These dramatic manifestations of rural discontent shocked the country in part because they appeared during a generally tranquil period. 
If La Convencion Valley was a "traditional" agrarian area, how can we account for the mobilization? Certainly, the tensions introduced by modernization processes created the conditions that led to peasant organization by altering the patron-client relations in a manner that was unfavorable to the peasant. ${ }^{154}$ Charles Tilly reminds us that structural changes will affect the rules of collective action and will alter the way people act together in pursuit of shared interests. ${ }^{155}$

The conditions that made this area the seat of rural mobilization have been treated in this study. In tracing causes for the absence of previous protests and the new challenges posed by resistance, key conditions of rural setting were identified: the land and the patron-client relationship. The analysis of the area's land structure served to distinguish among different social segments in the rural society, uncovered the dialectic of internal contradictions in the relations between the classes, and pointed to the causes of the mobilization itself by revealing the new configuration that followed social change. Then by focusing on the explanatory device of patron-client relationship, in the context of the articulation of modes of production method, the social transformations were revealed, as they were taking place. Under these conditions, a new form of relationship was generated, this time involving the 
arrendire. These changes aided the rise to political prominence of the cholo, as embodied by the arrendire.

The initiating factor of change was the introduction of the coffee into a region that, with the exception of few coca producing haciendas, was traditionally based on subsistence agriculture. Coffee as a cash crop did not necessarily require major capital outlays; production could be combined with the growing of foodstuffs. Harvesting and processing were labor intensive procedures.

Jeffery Paige contends that "the social organization of the coffee production," that is, of the wet-processed coffee, was the source of the peasant movement in La Convencion, and that in areas where dry-processing was used, the hacienda system remained intact. ${ }^{156}$ Accordingly, the processing of the arabica coffee through two distinct phases, increased its profitability to the tenant farmer and created the conditions for more socialization among the peasants, leading to the development of dyadic relationships previously non-existent among the tenant-farmers. ${ }^{157}$ In general, structural conditions that affected peasant actions included the degrees and bases of solidarity within the community, the degree of autonomy and control from the landlords and the relations of the state's coercive sanctions against the peasants' collective actions. ${ }^{158}$ 
In La Convencion, where the typical communal village was absent, prior to peasant labor organization, the peasant settlement pattern on the hacienda consisted of widely scattered family units along the periphery of the landlord's cultivated lands. ${ }^{159}$ This distribution was marked by high a degree of isolation and very limited social contact. However, only after the development of peasant unions, the tenant farmers began a process of cohesion, based on greater orientation toward the community.

Indeed, the data on rural mobilization in southern highlands indicate a direct relationship between the existence of independent peasant communities, coffee production, and degrees of mobilization. Because, in the absence of comunidades indigenas, mobilized communities predominantly engaged in coffee production generated a higher degree of solidarity than those retaining other types of crops, the emphasis remained on land tenure patterns rather than specific crops as being favorable to mobilization. ${ }^{160}$

Available evidence on land ownership in comparable areas where haciendas survived shows that the principle of private property was introduced at the earliest stage of colonization. Moreover, there are indications that during the period referred to as the "fiebre del cafe," investors recreated the hacienda by accumulating large tracts of land for the purpose of coffee plantations. ${ }^{161}$ Analysis of the hacienda system 
exposes this institution to be the locus of all the contradictions that affected the agrarian structure in the valley, the monopoly over land and market exercised by the landowners, and the emergence of the arrendires as a determinant group who would take over the organization of production. ${ }^{162}$

Direct contact between the merchant and the arrendires increased the participation of the tenant in the economy, resulting in the accumulation of capital and the formation of the internal market. Although the availability of capital, allowed the tenants to invest in the land, thereby continuously raising productivity, further increases in coffee output could be achieved only by expanding the area under cultivation or hiring more workers. The preservation of precapitalist relations of production, in the form of the condiciones, had important consequences for the development of agrarian capitalism.

This study of labor relations in La Convencion has established that capitalist relations of production based on wage labor were articulated with precapitalist relations based on labor service, and, in effect, reinforced each other. Capitalism was the mode of production in the valley before the era of mobilization, as evidenced by the presence of wage labor and by the market basis of production. The 
precapitalist relations of production neither maintained nor determined the conservation of institutional arrangements such as condiciones; nor did they restrain the development of agrarian capitalism. Consequently, once the arrendires were free of obligations, some of them found it cheaper to lease out a small parcel of land to the allegado in exchange for his labor service both on the hacienda and the arriendo. Others, from among the arrendires who had settled earlier, relied on wage laborers rather than land transfer, or used both methods to ensure an available labor force. This was significant because it resulted in the emergence of rich, middle, and poor strata of peasants, and sanctioned the development of an acute form of class struggle among them over the reproduction of non-demesne property relations. In this process the rich and middle peasants displaced their poorer counterparts.

In this rural environment, the arrendires represented the most dynamic element at the core of the development of capitalist mode of production in agriculture. They had an objective to be achieved through mobilization; that is, to gain ownership of the land. Following Joel Migdal's analysis, the arrendires were the peasants who underwent the most rapid exposure to market forces, and would be the ones to respond to political stimuli involving solutions to their

market-induced problems. By contrast, Popkin suggests that some peasants will break out of traditional relationships by 
cultivating new ties, and that mobilization will be the outcome of self-interest rather than a function of pre-existing solidarity. Therefore, the organization of the tenants in peasant unions was the arrendires' political reaction to the landlords' attempt to take over the tenant-cultivated lands. Through these formal organizations the arrendires altered the traditional patron-client balance and other kinship ties, thus giving prime importance to new social structures within the hacienda system.

The political demands of the peasants reflected the economic interests of their leadership. To maintain the alliance with the allegados and sub-allegados against the landlords, the arrendires included demands for higher wages, the eight-hour work day, education, and improvements in their working conditions as part of their general objectives. The peasant unions, and later the Peasant Federation of Cuzco, became the only channels for any peasant and hacendado relations. Moreover, the unions represented the final break in the patron-client relationship. The heterogenous composition of the peasant unions is significant because it represents a multi-class alliance.

The use of dissent to overcome the traditional influence of the landlord suggests the presence of arrendires' rational interests in contrast to the traditional bonds existing in the hacienda system. The traditional elites' resistance to change 
was the point of departure in the strategy of formation of peasant organizations as a negative reference group to stimulate cohesion among the peasants. Thus, the fact that the formation of the peasant unions was strongly opposed and perpetuated a conflictive situation had a positive effect. It helped the arrendires to strengthen the cohesion of the peasant unions, and it offered an example of proactive action on their part. ${ }^{163}$ Hence, the local elite's orientation influenced the actions of the subordinate groups. The elevation of the cholo segment was facilitated by absentee ownership, but the limited patronage cholos could afford and the weakness of their ties to the rest of the rural strata promoted for a while, the further radicalization of other factions.

The arrendires/cholos became the rural bourgeoisie, allied with merchant capital and opposed to the landlords. The rural proletariat, dependent for its survival on the arrendires, did not achieve the unity of purpose or consciousness required to be a class. The allegados and sub-allegados became the petty-bourgeoisie on its way to proletarianization. The realignment of the valley's social stratification was the product of the arrendires' desire to free themselves from the obligations that tied them to their patrons. Introducing the allegado, and the sub-allegados, who substituted for the arrendires' labor service on the hacienda, 
was the initial fragmentation in the dependence of the tenant on his hacendado; the establishment of the peasant unions represented the final break.

For the cholo segment, the goal of collective action was political power; they were therefore interested in maintaining the economic incentives as a collective good in order to preserve the momentum generated by mobilization. The cholo leaders realized that only separate and "selective" incentives would stimulate a rational individual to act in a group-oriented way. The "selective incentives" offered were either negative or positive, in that they could either coerce by punishing those who failed to bear the costs of the group action, or they could induce those who acted in the group interest. ${ }^{164}$

The arrendire/cholo group offers similarities to Moncur Olson's "latent group." According to Olson, such a group can become a "mobilized" latent group through the use of either coercion or positive rewards. By using the collective good as the main appeal and the selective incentives as an additional stimulus, the unions performed their function; that is, satisfied a demand, furthered an interest, or met a need for a large number of people. No other means could do any longer. The direction of the mobilization was conditioned by the arrendires' ideological position. Consequently, the mobilization became segmented into well defined zones: the 
reformist zone, under the influence of the Peruvian Communist Party, at the time that the party ideology espoused support for the national bourgeoisie's effort to eradicate feudalism; and the radicalized zone led by Hugo Blanco, who advocated revolution. It should be stressed that the arrendires group who owned an average of 17 hectares a piece became the most militant element in the mobilization, and not the arrendires who possessed parcels with an average of five hectares each. The rich tenant farmers, the most progressive component in the mobilization, gave their political support to Blanco, because he was the only one involved in the struggle for ownership of land. Finally, the peasant unions, influenced by the FTC and APRA, were more conciliatory and institutional in their approach to the problems between the hacendados and the peasants. The early leadership's organizational expertise indicated, not only the party's influence but also a higher level of acculturation, with sufficient skills to adapt the urban trade unions' model to the rural environment.

Popkin, Migdal, and others do not underestimate the revolutionary abilities of certain middle-class rural strata, but they all believe in the need for external influence and help in the process of building a mobilization superstructure. In La Convencion, however, this did not obtain, because PCP especially, and to a lesser extent APRA, began to penetrate 
the surrounding highlands in the 1930s. The improved quality of education in the provincial center of Quillabamba aided the maturation of the cholos as effective and knowledgeable leaders. Many of them maintained contacts with the highland villages from which they had originally migrated and became influential actors in furthering the mobilization of the Quechua communities in the surrounding highlands. Consequently, this group of professional cholos emerged as successful political leaders in many of Peru's rural areas. ${ }^{165}$

The traditional basis of the ethnic relations within the old caste like system had been reconstituted by the conquest. Apart from the Indian nobility, the mass of the indigenous population was transformed into a peasantry. ${ }^{166}$ In time, a thorough mestization occurred, often attended by a cult of indigenismo, glorifying an Inca utopia. But mestizo culture is essentially Hispanic and in rural areas many of the elites were mestizos.

The department of Cuzco, forms part of the region known as Mancha India, which encompassed the areas of Ancash, Apurimac, Ayacucho, Puno, and Huancavelica. ${ }^{167}$ The demographic changes in the valley indicate that the bulk of migration to the area took place from the Mancha, but no single province served as the major source of migrant labor. Based on the available data on the ethnic factor in the 
mobilization in La Convencion, and judging from other situations in Peru, it can be presumed that in the process of out-migration from their native communities many of the tenants acquired new status. Often the migrant peasants from the sierra were smallholders themselves, who saw in becoming an arrendire or allegado as a new challenge, and opportunity to improve on the former condition. The consequently high degree of tension can be a corollary on how the hacendados perceived their tenants and the tenant-farmers' self-identity, and the developing struggle resulted from societal inconsistencies rather than from ethnically based competition. ${ }^{168}$

By the middle 1950s, during the period of the convivencia, the state had become the most important agent for social change in the southern highlands. Theda Skocpol advises us on the importance of the timing of the peasants' revolutionary potential in conjuncture with the role of the state in the context of world historical development. The centralized state, representative of the coastal bourgeoisie's interests, undertook public works projects, entered and regulated the labor market, and through direct intervention, weakened the hacendados' hold on the rural population. It supported the development of agrarian capitalism, and placed it itself between the peasant and the landlord in an effort to undermine the power of the landlords. 
By the late 1950s, the emergence of a labor surplus in agriculture broke the logic of internal subsistence and provided the objective conditions for the state intervention, thereby attempting through legal course to eliminate the remnants of precapitalist social relations. The state's logic was geared to the development of agrarian capitalism in order to increase food production and agricultural exports that would meet the urban middle class's need for cheap food and foreign exchange requirements for industrialization. The state could meet those goals could be met only by relaxing its traditional sanctions against political organizing. It was exactly at the same time, that unionization efforts in La Convencion increased. The acceleration of the process of mobilization, in defense against the hacendados' increased demands, can be directly related to the political freedom policies implemented by the Prado administration through the strategy of convivencia.

During the 1950s, the spread of technological innovation in the sugar industry along the coast coincided with rapid increases in the available labor supply from the sierra. This, in turn, caused labor surplus conditions, and as a consequence, the government promotion of migration to new colonizing areas. Nevertheless, agricultural laborers and seasonal laborers constituted the bulk of the migration to the valley, and very few new tenancies were established. Could 
there be any correlation between the type of individuals migrating to new regions, the forms of labor and land control, and state intervention? Studies in Andean seasonal migration show that individuals respond to market forces and rationalize their distribution of labor from among productive regions. Furthermore, the choice of migrants is influenced by their relations with both the local elites and the state. ${ }^{169}$ We have no studies on the migrations in La Convencion, though we do know more about the neighboring areas involved in coffee production. They show that, in support of the commercial interests in the altiplano, the merchants attempted to consolidate their control on the coffee market and kept the price down by favoring smallholder production. Ultimately, the confrontation between the different elite fractions, in pursuit of short-term interests, undermined coffee production. ${ }^{170}$

The penetration of capitalism in the agrarian sector proved to be a slow process, and in the end it connected remote areas to the world market. World coffee prices and, in general, the world economic cycle, directly affected the course of the mobilization. The international context thus becomes important as it impinges upon national development. ${ }^{171}$ The immediate reference to the effects of the Cuban Revolution on the direction of the mobilization in 
La Convencion highlighted the Blanco faction's use of the slogan "Land or Death." 172

Students of agrarian conflict generally agree that the penetration of capitalism and its consequent development will cause changes in rural areas that will affect the peasantry. The issue still remains as to the role of the peasants as defendants or as instigators.

It has become evident that we cannot look at an event, like the one described here and evaluate it from the point of view of one all-encompassing social theory. In the attempt to develop testable generalizations regarding rural mobilization in coffee-producing areas, the need is for comparative historical work rather than individual case studies. 
NOTES

1. Wesley Craig, "From Hacienda to Community: An Analysis of Solidarity and Social Change in Peru," Ph.D. diss.,(Cornell University, 1967), passim.

2. This terminology was used only in the valleys of La Convencion and Lares; therefore it needs clarification. In formulating the definitions I followed the explanations outlined by Eduardo Fioravanti in Latifundio y sindicalismo agrario en el Peru: el caso de los valles de La Convencion $y$ Lares (1958-1964) (Lima: Instituto de Estudios Peruanos, 1974). Arrendire represents the peasant who leased a parcel of land from the hacendado, in exchange for a pre-determined number of days in labor-service and an additional payment, (canon), in money. The arrendire is also an arrendatario. Allegado is the peasant who entered an agreement with the arrendire. He received the use of a parcel of land, in exchange for substituting for the arrendire in fulfilling the arrendire's obligation to the landlord. Unlike the arrendire, the allegado, may not have a written contract but he was doubly dependent. Legally, the allegado is a subarrendatario of the land. Sub-allegado describes the allegado of the allegado. He received a "micro-parcel" of 
land of the allegaduria in exchange for relieving the allegado of his obligation with the hacendado and the arrendire.

3. Here I adopt the definition for peasant as espoused by $A$. Douglas Kincaid in Agrarian Development, Peasant Mobilization and Social Change in Central America: A Comparative Study (Ann Arbor: U.M.I., 1987), 5.

4. Karl W. Deutsch, quoted in Henry A. Landsberger and Tim McDaniel, "Hypermobilization in Chile, 1970-1973" in The State and Development in the Third World, ed. Atul Kohli (Princeton: Princeton University Press, 1986), 172.

5. Samuel P. Huntington, Political order in Changing Societies (New Haven: Yale University Press, 1968), 265. 6. Ibid., 73 . 7. Ibid., 75 . 8. Ibid., 308 .

9. For Moore, the key organizational concept is modernization through revolution, and the causal variables depend upon the choice from three alternative routes available to the modern world: (a.) through bourgeois revolution to liberal democracy; (b.) through revolution from above to fascism; (c.) through peasant revolution to communism. Moore states that although countries took one of the alternative routes to modernization, it may work as successive stages with limited determinate relation to each other. 
10. The cases of La Convencion in Peru, Cochabamba in Bolivia, and La Violencia in Colombia are examples of rural mobilizations that were not primarily based on the land issues, but instead on the nature of relations between lord and peasants.

11. At a more advanced stage of development, with the disappearance of common rights and the performance in common of certain tasks during the agricultural cycle, the overwhelming importance of the small plot worked by family labor, and the competitive relationships, created the atomized peasant village that became the center of reactionary anticapitalist sentiment in the countryside.

12. Theda Skocpol, States and Social Revolutions: A Comparative Analysis of France, Russia and China (Cambridge: Cambridge University Press, 1979), 114-16.

13. Ibid., 116.

14. Ibid., 114 .

15. Joel Migdal, Peasants, Politics, and Revolutions: Pressures toward Political and Social Change in the Third World (Princeton: Princeton University Press, 1974), 226. 16. Ibid., 87 .

17. Ibid, , 13 .

18. Eric Wolf, Peasant Wars of the Twentieth Century (New York: Harper and Row, 1973), 295.

19. Ibid., 277. 
20. Ibid., 298.

21. James C. Scott, "Hegemony and the Peasantry," Politics and Society $7,(1977): 277$.

22. Douglas Kincaid, Agrarian Development, Peasant Mobilization and Social Change in Central America, 24-25.

23. Scott in the article "Hegemony and the Peasantry" uses Gramsci's concept of hegemony to discuss the differences between the proletariat and the peasantry. While the former accepts the legitimacy of exiting social relationships and confines the class struggle to financial improvements, the peasantry's isolation -geographical and ideological- renders less vulnerable to the same condition.

24. Samuel Popkin, The Rational Peasant: The Political Economy of Rural Society in Vietnam (Berkeley: University of California Press, 1979), 80 .

25. Samuel Popkin, "The Rational Peasant: The Political Economy of Peasant Society," Theory and Society 9 (1980): 434,464 .

26. Robert Brenner, in Popkin The Rational Peasant, 77.

27. Lynn Hunt, "Charles Tilly's Collective Action" in Vision and Method in Historical Sociology (Cambridge: Cambridge University Press, 1984), 246.

28. Ibid., 247.

29. Ibid., 251. 
30. He was referring not only to the circumstances under which the rent in kind, labor, or money arise, but the conditions that would lead to change from a natural form of surplus to an excess of surplus over profit.

31. Jeffery Paige, Agrarian Revolutions: Social Movements and Export Agriculture in the Underdeveloped World (New York: The Free Press, 1978), 1-71.

32. Ibid., 62 .

33. Marx also referred to the Asiatic mode of production, in which primitive communities were combined with state power that controlled essential economic resources.

34. Ronaldo Munck, Politics and Dependency in the Third World: The Case of Latin America (London: Zed Books, Ltd.), 28 .

35. Aidan Foster-Carter, " The Modes of Production Controversy," The New Left Review 107 (January-February 1978): $52-3$.

36. Ibid., 61 .

37. Other Marxists reject the notion of "underdeveloped" or "modernizing society" in favor of "transitional social formations." For additional information see John Taylor, From Modernization to Modes of Production.

38. Foster-Carter, "The Modes of Production Controversy," 61 . 
39. Dani Rodrick, " Rural Transformation and Peasant Political Orientation in Egypt and Turkey." Comparative Politics 14 (July 1982): 418 .

40. Ibid., 418 .

41. Steve J. Stern " New Approaches to the Study of Peasant Rebellion and Consciousness: Implications of the Andean Experience." Resistance, Rebellion, and Consciousness in the Andean Peasant World (Madison: University of Wisconsin Press, $1987): 5$.

42. Ibid., 9 .

43. Ibid., 9 .

44. Ibid., 10 .

45. Ibid., 12 .

46. Ibid., 13.

47. Ibid., 3-18.

48. Their success did not include, however, the nearby Aymara people inhabiting the altiplano.

49. The crown, having pre-empted rights over the conquered lands and peoples, was able to reward the conquistadores by granting them the right of lordship over native settlements; that is, an encomienda. These rights were granted for the duration of the grantee's life and that of his heir.

50. There were close to five hundred encomenderos in Peru when the system was gradually phased out. 
51. From the beginning, the reducciones were composed of a number of ayllus through which the members of Indian community received access to water and the labor of their fellows. 52. Edward Dew, Politics in the Altiplano, the Dynamics of Change in Peru (Austin: The University of Texas Press, 1969), mentions Kubler who wrote that, in Chucuito Province whence once of the great mitas were levied for the mines at potosi, the Indian population sank by two-thirds between 1628 and 1754 .

53. Karen Spalding, "Class Structure in the Southern Peruvian Highlands," Land and Power in Latin America: Agrarian Economies and Social Processes in the Andes eds.Benjamin Orlove and Glynn Custred (New York: Holmes and Meiex Publishers, 1980), passim.

54. The Spanish army, in the 1743 expedition against Atahualpa, requisitioned the services of arrieros from Huarochirri to transport supplies, food and munitions, instead of Tarma and Juaja which were closer. The precaution proved worthless, since on the way to their destination the arrieros disappeared with their loads. A similar betrayal involved the massacre of a small colonial group in 1747. Serrano sympathies became evident in their attitude toward Atahualpa's incursions. In 1742-43, the rebel forces made several threatening incursions into the highlands, and yet they always escaped. That indicates support from the local population in 
the form of guerilla groups, to cover the rebel forces' retreat.

55. Fredrick B. Pike, The Modern History of Peru (New York: Frederick A.Praeger Publishers, 1967), 33.

56. Arriero is a person who raises and owns mules for transport purposes.

57. Richard N. Adams in Community in the Andes, wrote that: "in the 1710 land conflict between the communities of the Yanamarca Valley and the hacienda Yanamarca, the ayllu Allauca (later the community of Acolla) is represented by its cacique. By 1791, the community of Acolla is represented by Ilario Angaroca, alcalde ordinario." 47.

58. The outsiders, or "marginals," were the merchants, and the mine owners who bought land for speculation. These people had an important role in promoting the development of capitalism in the highlands.

59. Pike, The Modern History of Peru, 46.

60. John S. Gitlitz in Hacienda, Comunidad, and Peasant Protest in Northern Peru states that the 1824 law prohibited the sale of land before 1850; which restrictions the 1825 decree revised.

61. Dew, Politics in the Altiplano, 28.

62. In formulating the definition of comunidad I used the explanation outlined in Land and Labor in Latin America eds. Kenneth Duncan and Ian Rutledge (Cambridge: Cambridge 
University Press, 1977), 493. A comunidad is a freeholding rural community; sometimes required to conform to a set of legal norms to qualify for legal recognition.

63. John Fisher, "Royalism, Regionalism, and Rebellion in Colonial Peru, 1880-1815," Hispanic American Historical Review $59($ May 1979): 232 .

64. Henry A. Landsberger, "The Role of Peasant Movements and Revolts in Development," in Latin American Peasant Movements (Ithaca: Cornell University Press, 1969), 23.

65. Florencia Mallon, The Defence of Community in Peru's Central Highlands (Princeton: Princeton University Press, 1983), 49 .

66. When the Spanish conquistador Francisco Pizarro and his companions landed on the northern coast of Peru in the early sixteenth century, the city of Cuzco was the seat of the Inca empire.

67. A hectare is a unit of land measure, equivalent to 2.471 acres.

68. William Foote Whyte and Giorgio Alberti, Power, Politics and Progress: Social Change in Rural Peru (New York:Elsevier 1976), 38-9.

69. E.J.E. Hobsbawn, "A Case of Neo-Feudalism: La Convencion, Peru," Journal of Latin American Studies 1(1969): 31-50 70. Wesley W. Craig, "Peru: The Peasant Movement of La 
Convencion" in Latin American Peasant Movements ed. Henry A. Landsberger (Ithaca: Cornell University Press, 1969), 274-80. 71. Beyond the eastern slopes of the Andes lies the jungle or selva, the third geographical region of Peru. This jungle covers over half of the nation's territory yet its economic, political, and social relevance is minute, because it is largely unpopulated. Its sparse population, some 9 percent of the national total, is composed of isolated aboriginal tribes. 72. Craig, "Peru: the Peasant Movement of La Convencion," 278 .

73. Dew, Politics in the Altiplano, 28.

74. Eduardo Fioravanti, Latifundio y sindicalismo agrario, p.20 In 1909, the Law 1200 also known as Ley de Tierras de Montana was promulgated. It established four different ways to acquire land: purchase, concession, as a consequence of a judgement award and claims.

75. Solon Barraclough, Agrarian Structures in Latin America (Lexington: Lexington Books, 1973), 265-70.

76. David Scott Palmer, "The Politics of Authoritarianism in Spanish America" in Authoritarianism and Corporatism in Latin America ed. James Malloy (Pittsburgh: University of Pittsburgh Press, 1977), 395.

77. The owners of large sierra estates were unchecked lords of their kingdoms. By 1900s, they focused their attentions on national politics, and consequently they were elected to 
congress. Once installed therein these landowners, referred to in Peru as gamonales, became the puppets of the president. Dependent on them, the president was not inclined to restrain their powers as absolute "caciques" in the highlands. The gamonales imposed semi-feudal methods of force to enlarge their estate holdings at the expense of Indian communities. 78. I am using Irving Louis Horowitz's criteria in defining the masses, in Masses in Latin America (New York: Oxford University Press, 1970), 5-9. Masses are those people excluded from decision making in politics, from ownership or managerial participation in business and industry, from educational institutions, and from power processes. According to Horowitz, this definition makes it possible to have low-status characteristics without being part of a mass. Yet a question remains unsolved; namely, whether mass and class are properly a matter of consciousness and value rather than of social interest.

79. In newly colonized areas like La Convencion, and Satipo draft labor on public works was renamed from mita to faena. 80. Andrew Pearse in The Latin American Peasant (London: Frank Cass \& Co. Ltd., 1975), 162-5.

81. Scott Palmer, "The Politics of Authoritarianism," 397 .

82. During this period there were signs of restlessness in the highlands, central and southern. The rural uprisings that 
characterized the 1920s, were caused by the penetration of capitalism into the remote areas, inflicting changes on the prevailing nature of land use between the peasant villages and the neighboring haciendas.

83. Howard Handelman, Struggle in the Andes (Austin: The University of Texas Press, 1975), 31. By 1958, in the area of Cuzco, out of a total of 1,895 indigenous communities 204 were recognized, and 1691 unrecognized.

84. Gitlitz, Hacienda, Comunidad, and Peasant Protest 23, comments on the legal involvement of the Indian communities that

Many comunidades, legally recognized or not, continued to have active conflict with the neighboring hacendados. Of 732 comunidades studied by Dobyns, 73 percent were actually involved in legal disputes. Of 39 studied by Martainez in central Peru 73 percent did legal battles -43 percent with hacienda and 30 percent with other comunidades. The CIDA study reports the case of Huaylachulo, which in 1965 controlled only 750 acres but which had legal suits for 49,250 acres more.

85. Ley 4113, of May 10, 1920, cited by Dew in Politics in the Altiplano, established that, obligatory road work for all 
male residents of the country between the ages of 18 and 60 , was required, or the payment of a fine equivalent to the worth of the work assigned to them.

86. The case analyzed by Robin Schoemaker in The Peasants of El Dorado, suggests that the lineal settlement pattern along the line of communication, are in sharp contrast to the radial settlement plan in most peasant societies. In a lineal arrangement, the households are scattered along the routes of communication and each family lives and works on a single plot of land. The population is highly dispersed. The ultimate goal is permanent settlement and intensive exploitation of the environment.

87. Craig, "Peru: The Peasant Movement of La Convencion," 279-80, and E.J.E. Hobsbawm, "A Case of Neo-Feudalism: La Convencion, Peru," 33-5.

88. Shortly after overthrowing Leguia, General Sanchez Cerro removed the property qualification for the right to vote. 89. The APRA ideology as espoused by Haya de la Torre contained many inconsistencies. One of this referred to the line taken by the party towards imperialism. At the time he and other apristas were calling for a concerted effort to end imperialism, to introduce socialism, and to accomplish economic and social reform in Indo-America, Haya de la Torre was revisiting Marxism-Leninism along the following lines. He agreed that imperialism was the last stage of capitalism, 
but only in the developed states, in the highly capitalized countries. In contrast, imperialism in underdeveloped countries was the first stage of their capitalism. Hence, these countries must encourage the imperialist process for it would create the capitalism which would generate a powerful proletariat, which in turn together with the middle sectors would lead the socialist revolution.

90. As early as 1930, Communist activists already were intensifying their recruiting activities among the workers to form the General Confederation of Peruvian Workers, or Confederacion General de Trabajadores Peruanos. By the end of 1930 they were claiming a membership of over 56,000 industrial workers and an additional of 8,000 unemployed. The Confederation organized a number of "Jose Carlos Mariategui Worker and Peasant Schools" to teach technological skills and ultimately to instruct the lower classes in revolutionary activity. The confederation's activities in the sierra escalated so that, by the beginning of 1931, it claimed an affiliation of 30,000 campesinos.

91. Craig, "Peru: The Peasant Movement," 282.

92. Ibid., 282-83.

93. Wesley Craig, "From Hacienda to Community: An Analysis of Solidarity and Social Change in Peru," Pd. D. diss.(Cornell University, 1967): 30 . 
94. Jane L. Collins, Unseasonal Migrations: The Effects of Rural Scarcity in Peru (Austin: University of Texas Press, $1975), 153$.

95. Robin Schoemaker in The Peasants of El Dorado: Conflict and Contradiction in a Peruvian Frontier Settlement (Ithaca: Cornell University Press, 1981), studied the effects of coffee cultivation in the area of Satipo, north of La Convencion. He found that before the coffee boom, small family farms, rarely exceeding fifty hectares, were the basic units of agricultural production. But when coffee prices began to soar, investors began to purchase unused land from the state, and small farmers were absorbed into growing coffee estates of over 1,000 hectares. The elite of prominent coffee growers controlled the social and economic life of the satipo community.

96. Arthur Stinchcombe, "Agricultural Enterprise and Rural Class Relations," The American Journal of Sociology 67 (September 1961): 167 .

97. Anibal Quijano, quoted in Handelman, struggle in the Andes, 174 .

98. Rosemary Thorp and Geoffrey Bertram, Peru 1890-1977 (New York: Columbia University Press, 1978), 274-80.

99. Handelman, Struggle in the Andes, 76-80.

100. Craig, "From Community to Hacienda," 40-49; Fioravanti, 
Latifundio y sindicalismo, passim, and Handelman, struggle in the Andes, 62-83.

101. Fioravanti, Latifundio y sindicalismo agrario, and Collins, Unseasonal Migration, passim. In comparison, in the department of Puno, a change in the political alliances cleared the way for state intervention in the coffee production. The coffee cooperatives did not only serve to rationalize the control of highland merchants over the coffee commerce but were used by the state to further its own concerns.

102. In contrast to other areas, in the newly colonized region of the montana the land belonged to the state (the national government) but could be claimed by individuals for a small fee. The principle of private ownership became a determining factor in the frontier society.

103. According to Eric Wolf, a byproduct of the trade system established under the crown had been a group of "marginals" small shopkeepers, merchants, middlemen, casual farmers, and specialized workers located in the villages and communities near mines, haciendas, or mills. Peasant Wars of the Twentieth Century (New York: Harper \& Row, 1973).

104. Robert G. Keith, "Introduction," in Haciendas and Plantations in Latin American History (New York: Holmes and Meier Publishers, 1977), 3. 
105. Eric R. Wolf and Sidney W. Mintz, "Haciendas and Plantations," in Haciendas and Plantations in Latin American History ed. Robert G. Keith, 40.

106. In Chapter 2, part two, I mentioned the early land grants and the development of the area in the sixteenth century.

107. E.J.E. Hobsbawm, "A Case of Neo-Feudalism," 33. 108. Marc Bloch, French Rural History trans. Janet Sondheimer, (Berkeley: University of California Press, 1966), 65 .

109. Hobsbawm, "A Case of Neo-Feudalism," 33-34, suggests that the available records are not very reliable.

110. Ciro F. S. Cardoso," The Formation of Coffee Estate in Nineteenth Century Costa Rica" in Land and Labour in Latin America, ed. Malcolm Deas, Clifford T. Smith and John Street (Cambridge University Press, 1977): 168.

111. Hobsbawm, "A Case of Neo-Feudalism," 35, note 12. 112. Ibid., 35-36.

113. Coffee Production, La Convencion: 1945-1960

Year

1945

1950

1954

1960
Total Production, in Kilos

583,252

772,000

$1,308,349$

$3,820,116$ 
Average Annual Price for Coffee in La Convencion in Soles per Kilogram

1945

1946

1947

1948

1949

1950

1951

1952

1953

1954
1.21

1.27

3.26

3.97

4.06

7.15

7.83

9.01

9.63

14.77
Price Index:

$1945 \quad 100$

$1954 \quad 1,221$

Source: Craig, "From Hacienda to Community," 31-32.

114. Gerrit Huizer, The Revolutionary Potential of Peasants in Latin America (Lexington: Lexington Books, 1972), 114 .

115. The data regarding the size and number of the haciendas are confusing. When comparing data from the writings of Wesley Craig, Edward Dew, Eduardo Fioravanti, E.J.E. Hobsbawm and Solon L. Barraclough they do not match. Most of these writers include information pertaining to haciendas in the Lares province, because it abuts La Convencion, and it presented similar socioeconomic conditions. The mobilization quickly spread there, and by 1959 the unions from the Lares province were incorporated into the main peasant federation from La Convencion.

116. Fioravanti, Latifundio $y$ sindicalismo, 35. The following list represents the nine major haciendas with 10,000 or more hectares, their tenants and the land they each occupied: 
1. hectares used by tenants, 17.0 average/tenant.

2. Hda Chancamayo, 36,332 hectares, 271 tenants, 3,849 hectares used by tenants, 14.2 average/tenant.

3. Hda Huyro, 30,020 hectares, 666 tenants, 2,750 hectares used by tenants, 4.1 average/tenant.

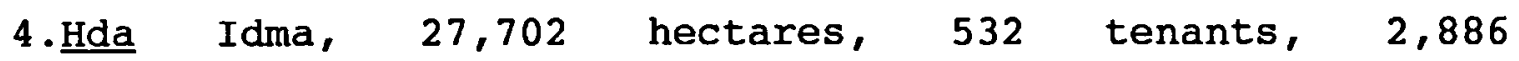
hectares used by tenants, 5.4 average/tenant.

5. Hda Tablahuasi,20,000 hectares, 31 tenants,359 hectares used by tenants, 11.6 average/tenant.

6 . Hda Occobamba, 15,564 hectares, 12 tenants,204 hectares used by tenants, 17.0 average/tenant.

7. Hda Echarate, 14,145 hectares, 668 tenants, 3,715 hectares used by tenants, 5.6 average/tenant.

8. Hda Paltaybamba, 12,000 hectares,245 tenants, 1,483 hectares used by tenants, 6.1 average/tenant.

9. Hda Sahuayaco, 11,775 hectares, 260 tenants, 2,812 hectares used by tenants,10.8 average/tenant.

117. Tom Bass, "Trotskyism, Hugo Blanco and the Ideology of

a Peruvian Peasant Movement" The Journal of Peasant Studies 16(January 1989): 174-76. For Trotsky, "dual power" is simply one phase of a continuous two-stage revolutionary transformation. The initial stage corresponds to the struggle between feudal landlords and the bourgeoisie, and the 
subsequent stage involves of the struggle between bourgeoisie and the 'third power' or the proletariat.

118. Hobsbawm, "A Case of Neo-Feudalism," 38, and Fioravanti, Latifundio y sindicalismo Agrario, 43.

119. C.D. Scott, "Peasants, Proletarianization and the Articulation of Modes of Production: The Case Sugar Cane Cutters in Northern Peru, 1940-1969," The Journal of Peasant Studies $3($ April): 328 .

120. Hobsbawm, "A Case of Neo-Feudalism," 39.

121. Scott in "Peasants, Proletarianization and the Articulation," views the engache, as a historically specific stage in the development of the regional labor market.

122. Craig, "Peru: The Peasant Movement," 280.

123. The system of habilitado not to be confused with what is known as habilidado system, as form of cash advance on future income. The coffee-exporting companies, through habilidador, middlemen or local merchants extended credit to the coffee growers. The farmer who received credit from a habillidador was under obligation to sell all his coffee harvest to the sponsoring firm. No interest was charged on the money borrowed, but the habilidador made his profit by paying the debtor a price 15 to 20 percent lower than the actual market value of the coffee. This system was present in most of the agricultural areas where the production was geared for export. 
124. Carl H. Lande, "The Dyadic Basis of Clientelism" in Friends, Followers, and Factions eds. Steffen w. Schmidt, James C. Scott, Carl H. Lande and Laura Guasti.(Berkeley: University of California Press, 1977), xiii.

125. Ibid., xiv.

126. Ibid., $\mathrm{xx}$.

127. In Peru the search for precious metals and the need for manpower lead the Spaniards towards the highland regions, of dense indigenous population. The spaniards concentrated on developing the coastal areas, for economic reasons and strategic, and more importantly to destabilize the Cuzco stronghold of the Inca civilization. Peru's incorporation in the world economy, as a supplier of primary and agricultural products was an additional catalyst to the colonization of the montana, an area between the highlands and the Amazon Basin. 128. He was an intermediary just like the Inca King, who represented humans among Gods and God among humans. Jan Szeminski, "Why Kill A Spaniard?" in Resistance, Rebellion, and Consciousness in the Andean Peasant World, 18th to 20th Centuries, 184 .

129. Sydel Silverman, "Patronage and Community-Nation Relationships in Central Italy" in Friends, Followers and Factions eds. Steffen w. Schmidt, James C. Scott, Carl Lande, and Laura Guasti (Berkeley: University of California Press, $1977), 296$. 
130. Hobsbawm, "A Case of Neo-Feudalism," 33-36, suggests that the cultivation of sugar cane involved certain seigneurial rights.

131. Ibid., 39-40.

132. Fioravanti, Latifundio y sindicalismo, 78.

133. Ibid., 23, 181 .

In Ia Convencion valley, there were approximately 4,000 arrendires in the area with 12,000 allegados and an unknown number of day laborers, altogether about 60,000 people.

134. Fioravanti, Latifundio y sindicalismo, 85-89.

When analyzing the condiciones for the arrendires on the hacienda Maranura it indicates that: in 1934 the total number of days for the turno at 40 centavos and maquipura at 50 centavos were 134 by 1934 the number of days in labor service were 156 at a price of 50 and 70 centavos respectively. Consequently, the hacendados increased the labor service requirements and at almost no expense for them. In 1934, the allegados had to complete for the hacendado 14 days of maquipura. By 1943 the allegados had to complete 12 days of maquipura at 70 centavos/day, 12 days of faena at 70 centavos/day, 12 days of palla at 40 centavos/day, with the additional 132 of palla performed by the women which total to 168 days of labor service rendered for the hacendado directly on the demesne. The allegado had the obligation to work for the arrendire, 78 days on the hacienda and 22 days on the 
arriendo. Therefore, the total number of days of labor service were 268, which seriously limited the sub-tenant's available time on his plot.

135. William F. Whyte and Giorgio Alberti, Power, Politics and Progress: Social Change in Rural Peru, 47.

136. Fioravanti, Latifundio y sindicalismo, 160.

137. William F. Whyte and Giorgio Alberti. Power, Politics and Progress: Social Change in Rural Peru, 47-48.

138. Craig, "From Hacienda to Community," 39.

139. Hugo Blanco Galdos was an agronomist and a political activist. He was the son of a lawyer from Cuzco, and he returned to the valley, in the late $1950^{\prime}$ 's, to work as an allegado. Ultimately, he represented the peasants in their early confrontation with the hacendados and was elected secretary general of the unions.

140. Craig, "Peru: The Peasant Movement," 287.

141. Fioravanti, Latifundio y sindicalismo, passim.

142. There is a relationship between the cyclic nature of a movement and the cyclic nature of the economy. Mobilization will begin to take place at the end of the upper cycle and a movement will peak at the lower level of the economic cycle. 143. Whyte and Alberti, Power, Politics and Progress, 39. 144. Gerrit Huizer, p.115

The entire property of over 100,000 hectares, belonged to the same family. What created the most indignation and 
belligerence among the peasants in Chaupimayo was the abuses of the landlord: for example, the continued practice of flogging those peasants who were not servile enough.

145. A few years later the Romainvilles were chased out of their hacienda. The hacienda Huadquina became the site of most dynamic peasant activities. Because of its size, the hacienda was divided, by the peasant leadership in four areas, and in each section a union was established.

146. Handelman in Struggle in the Andes, 70-110, mentions that the demonstration effect of the peasants, first in La Convencion and then in adjoining comunidades was felt through the department.

147. Whyte and Alberti, Power, Politics and Progress, 70-72. 148. Fioravanti, Latifundio y sindicalismo, 213. Primary education system in La Convencion and Lares in 1940 was represented by 41 schools, 3,358 students and 60 teachers. By 1962 there were 70 schools, 170 classrooms, 7,974 students and 147 teachers and during one year's period the number of schools increased to 87 , with 218 classrooms, 9,004 students and 189 teachers.

149. Craig, "Peru: The Peasant Movement," 287-90. 150. Tom Brass, "Class Formation and Class Struggle in La Convencion, Peru," Journal of Peasant Studies 7(July 1980): 432-37. 
151. Ibid., 427-57. After 1962, in many areas in the valley, labor service mechanism continued to be used in exchange for credit. Poorer peasants in need of money to support the household economy, entered in agreements with the rich farmers to work for them instead of repayment of debt with interest. 152. Huizer, The Revolutionary Potential, passim. While peasant organizations increasingly assumed the characteristics of a brokerage system, the flow of benefits is small, as the available resources. These organization seemed to serve the purpose of merely maintaining clienteles for local or national leaders.

153. Fioravanti, in Latifundio y sindicalismo, defines cholo, as the individual socially situated between an Indian and a mestizo.

154. Most often the material which I researched refers to the mobilization of the La Convencion $y$ Lares rather than only La Convencion.

155. Lynn Hunt, "Charles Tilly's Collective Action" in Vision and Method in Historical Sociology (Cambridge: Cambridge University Press, 1984): 244-74.

156. Paige, Agrarian Revolution, 170-85.

157. Fioravanti, Latifundio y sindicalismo, passim.

In traditional Andean peasant economy ayni corresponds to a dyadic relationship between two smallholders who agree to work on each other's land over a given period of time, while mink'a 
refers to a large work party called for a particular day, during which smallholders would discharge a day's labor owed to the peasant on whose land the work party takes place.

In La Convencion, however, such exchanges are called by the arrendires, and were organized not only by the employment of the substitute workers to whom wages are paid but by also by the social division of labor. For example, rich peasants linked by an ayni exchange not their personal labor but that of their workers, while middle and poor peasants exchanged their personal labor.

158. Theda Skocpol, States and Social Revolutions, 114-18.

159. Previously described in Chapter 3.

160. Craig, "From Hacienda to Community," 87-88.

161. I am referring to the data on the nature of landownership, coffee production and role of the state in El Salvador, Costa Rica, and Colombia.

162. See chapter 3 .

163. For "proactive" action, see Lynn Hunt's "Charles Tilly's Collective Action, "in Vision and Method in Historical Sociology ed. Theda Skocpol (Cambridge: Cambridge University Press, 1984): 244-78.

164. Moncur Olson,Jr., The Logic of Collective Action (Cambridge: Harvard University Press, 1965), 51.

165. Anibal Quinjano, in Gitlitz', Hacienda, Comunidad and Peasant, 54 . 
166. The Indian politically became a campesino. There is no exact translation of this word in the English language. Most often it has been used to mean "Indian" with a derogatory connotation. Generally it is used to mean peasant.

167. The communities from the Mancha constituted a reservoir of manpower for the haciendas in La Convencion whenever the owners wanted to extend the area of cultivation or replace tenant-farmers. This region, which comprised 29 percent of the country's total population, was overwhelmingly agricultural and used primarily the quechua language as its means of communication.

168. As cited by Wesley Craig, E.J.E Hobsbawm, William Foote Whyte and Giorgio Alberti.

169. Collins, Unseasonal Migrations, passim. 170. Ibid., 157-73.

171. In contrast to the position adopted by the followers of the dependency approach, which emphasized the "external factors" as causes for underdevelopment, Fernando E. Cardoso stresses the relevance of the historical processes that created the structures or "internal factors," that favor dependent development, and especially the relationship and the struggle between social classes.

172. Its immediate antecedents were other slogans with similarly revolutionary associations; hence Blanco's was a combination of "Land and Freedom" used by Emiliano Zapata in 
the 1911 Mexican Revolution and "Fatherland or Death" utilized by Castro during the 1959 Cuban Revolution. 


\section{BIBLIOGRAPHY}

BOOKS

Adams, Richard N. A Community in the Andes: Problems and Progress in Muquiyauyo. Seattle: University of Washington Press, 1959.

Alexander, Robert $J$. Communism in Latin America. New Brunswick: Rutgers University Press, 1969.

Archetti, Eduardo P., Paul Cammack and Bryan Roberts. Sociology of "Developing Societies": Latin America. New York: Monthly Review Press, 1987.

Badie, Bertrand and Pierre Birnbaum. The Sociology of State. Translated by Arthur Goldhammer. Chicago: University of Chicago Press, 1983.

Baron, Solo W. The Contemporary Relevance of History: A Study in Approaches and Methods. New York: Columbia University Press, 1986.

Barraclough, Solon. Agrarian Structures in Latin America. Lexington, Mass.: Lexington Books, 1973. 
Berghe, Pierre L. van den., and George Primov, eds. Inequality in the Peruvian Andes: Class and Ethnicity in Cuzco. Columbia: University of Missouri Press, 1977 .

Bloch, Marc. French Rural History. Translated by Janet Sondheimer. Berkeley: University of California Press, 1966.

Burns, Bradford E. Latin America: A Concise Interpretative History. Englewood Cliffs: Prentice Hall, 1990. - The Poverty of Progress: Latin

America in the 19th Century. Berkeley: University of California Press, 1980.

Cardoso, Fernando Henrique, and Enzo Faletto. Dependency and Development in Latin America. Translated by Marjory Mattingly Urquidi. Berkeley: University of California Press, 1979.

Carnoy, Martin. The State and Political Theory. Princeton: Princeton University Press, 1984.

Chaliand, Gerard. Revolutions in the Third World: Currents and Conflicts in Asia, Africa and Latin America. Translated by Diana Johnstone. New York: Penguin Books, 1977 . 
Chilcote, Ronald H. Theories of Comparative Politics. Boulder, Colorado: Westview Press, 1981.

Collins, Jane L. Unseasonal Migration: The Effect of Rural Labor Scarcity in Peru. Austin: The University of Texas Press, 1975.

Debray, Regis. Revolution in the Revolution? New York: Grove Press, Inc., 1967.

Dew, Edward. Politics in the Altiplano, the Dynamics of Change in Rural Peru. Austin: University of Texas Press, 1969 .

Duncan, Kenneth, and Ian Rutledge, eds., with collaboration Colin Harding. Land and Labour in Latin America: Essays on the Development of Agrarian Capitalism in the Nineteenth and Twentieth Centuries. Cambridge, England: Cambridge University Press, 1977.

Durrenberger, E. Paul, ed. Chayanov, Peasants and Economic Anthropology. Orlando: Academic Press, Inc., 1984 .

Evans, Peter, Dietrich Rueschemeyer, and Theda Skocpol, eds. Bringing the State Back In. Cambridge, Mass.: Cambridge University Press, 1985. 
Fanon, Franz. The Wretched of the Earth. Translated by Constance Farrington. New York: Grove Press, 1968.

Figueroa, Adolfo. Capitalist Development and the Peasant Economy in Peru. Cambridge, England: Cambridge University Press, 1984.

Fioravanti, Eduardo. Latifundio y sindicalismo agrario en el Peru: el caso de los valles de la Convencion y Lares (1958-1964). Lima: Instituto de Estudions Peruanos, 1974 .

Fisher, J.R. Government and Society in Colonial Peru: The Intendant System, 1784-1814. London: The Athlone Press, University of London, 1970.

Gibson, Charles. Spain in America. New York: Harper and Torchbooks, 1966 .

Gitlitz, John Stephen. Hacienda, Comunidad, and Peasant Protest in Northern Peru. Chapel Hill: University of North Carolina Press, 1975.

Glazer, Nathan, and Daniel P. Moynahan, eds. Ethnicity: Theory and Experience. Cambridge: Harvard University Press, 1975 . 
Handelmann, Howard. Struggle in the Andes: Peasant

Political Mobilization in Peru. Austin: The

University of Texas Press, 1975.

Hanke, Lewis, ed. History of Latin American Civilization: Sources and Interpretations. Vol.2 The Modern Age. Boston: Little, Brown and Company, 1967.

Harris, Marvin. Patterns of Race in the Americas. New York: W.W. Norton and Company, 1964.

Horowitz, Irving Louis, ed. Masses in Latin America. New York: Oxford University Press, 1970.

Huizer, Gerrit. The Revolutionary Potential of Peasants in Latin America. Lexington, Mass.: Lexington Books, 1972 .

Huntington, Samuel P. Political Order in Changing Societies. New Haven: Yale University Press, 1968. Johnson, John J.,ed. Continuity and Change in Latin America. Stanford: Stanford University Press, 1964.

Katz, Friedrich, ed. Riot, Rebellion and Revolution: Rural Social Conflict in Mexico. Princeton: Princeton University Press, 1988. 
Keith, Robert G. Conquest and Change: The Emergence of the Hacienda System on the Peruvian Coast. Cambridge: Harvard University Press, 1976.

Keith, Robert G., ed. Haciendas and Plantations in Latin American History. New York: Holmes and Meier Publishers, Inc., 1977.

Kincaid, A. Douglas. Agrarian Development, Peasant Mobilization and Social Change in Central America: A Comparative Study. Ann Arbor: U.M.I., 1987.

Klaren, Peter F., and Thomas J. Bossert, eds. Promise of Development: Theories of Change in Latin America. Boulder: Westview Press, Inc., 1986.

Kohli, Atul, ed. The State and Development in the Third World. Princeton: Princeton University Press, 1986.

Lambert, Jacques. Latin America: Social Structures and Political Institutions. Translated by Helen Katel. Berkeley: University of California Press, 1969.

LaMond, Tullis F. Lord and Peasant in Peru: A Paradigm of Political and Social Change. Cambridge: Harvard University Press, 1970. 
Landsberger, Henry A. ed., Latin American Peasant

Movements. Ithaca: Cornell University Press, 1969.

Landsberger, Henry A. Rural Protest: Peasant

Movements and Social Change. London: MacMillan Press, Ltd. , 1973 .

Langer, Erick D. Economic Change and Rural Resistance in

Southern Bolivia, 1850-1930. Stanford: Stanford University Press, 1989.

Lehmann, David, ed. Ecology and Exchange in the Andes. Cambridge, England: Cambridge University Press, 1982.

Lockhart, James, and Stuart B. Schwartz. Early Latin America: A History of Colonial Spanish America and Brazil. Cambridge: Cambridge University Press, 1986.

Long, Norman, and Bryan Roberts, eds. Miners, Peasants and Entrepreneurs: Regional Development in the Central Highlands of Peru. Cambridge, England: Cambridge University Press, 1984.

Lukacs, Georg. History and Class Consciousness: Studies in Marxist Dialectics. Translated by Rodney Livingstone. Cambridge: The MIT Press, 1968. 
Mallon, Florencia E. The Defence of Community in Peru's Central Highlands: Peasant Struggle in Capitalist Transition, 1860-1940. Princeton: Princeton University Press, 1983.

Malloy, James M., ed. Authoritarianism and Corporatism in Latin America. Pittsburgh: University of Pittsburgh Press, 1977 .

Mariategui, Jose Carlos. Seven Interpretative Essays on the Peruvian Reality. Translated by Marjory Urquidi. Austin: The University of Texas Press, 1988.

McClintock, Cynthia. Peasant Cooperatives and Political Change in Peru. Princeton: Princeton University Press, 1981.

Migdal, Joel S. Peasants, Politics, and Revolutions: Pressures toward Political and Social Change in the Third World. Princeton: Princeton University Press, 1974 .

- Strong Societies and Weak States:

State-Society Relations and State Capabilities In The Third World. Princeton: Princeton University Press, 1988 . 
Moore, Barrington Jr. Social Origins of Dictatorship and Democracy: Lord and Peasant in the Making of the Modern World. Boston: Beacon Press, 1966.

Morner, Magnus. The Andean Past: Land Societies and Conflicts. New York: Columbia University Press, 1985. Munck, Ronaldo, Politics and Dependency in the Third World: The Case of Latin America. London: Zed Books Ltd. , 1984 .

Olson, Mancur, Jr. The Logic of Collective Action: Public Goods and the Theory of Groups. Cambridge: Harvard University Press, 1965.

Orlove, Benjamin S., and Glynn Custred, eds. Land and Power in Latin America: Agrarian Economies and Social Processes in the Andes. New York: Holmes and Meier Publishers, Inc., 1980 .

Orlove, Benjamin S., Michael w. Foley and Thomas F. Love, eds., State, Capital and Rural Society: Anthropological Perspectives on Political Economy in Mexico and the Andes. Boulder: Westview Press, 1989. 
Oxaal, Ivar, Tony Barnett, and David Booth, eds. Beyond the Sociology of Development: Economy and Society in Latin America and Africa. London: Routledge and Kegan Paul, 1975.

Paige, Jeffery M. Agrarian Revolution: Social Movements and Export Agriculture in the Underdeveloped World. New York: The Free Press, 1978.

Pearse, Andrew. The Latin American Peasant. London: Frank Cass and Co. Ltd., 1975.

Pike, Frederick B. The Modern History of Peru. New York: Praeger Inc., Publishers, 1967.

Popkin, Samuel L. The Rational Peasant: The Political Economy of Rural Society in Vietnam. Berkeley: University of California Press, 1979.

Porter, Roy, and Mikulas Teich, eds. Revolutions in History. Cambridge: Cambridge University Press, 1983. Pryor, Frederic L. The Origins of the Economy: A Comparative Study of Distribution in Primitive and Peasant Economies. New York: Academic Press, 1977. 
Schmidt, Steffen W., James C. Scott, Carl Lunde and Laura Guasti, eds. Friends, Followers and Factions: A Reader in Political Clientelism. Berkeley: University of California Press, 1977.

Schoemaker, Robin. The Peasants of El Dorado: Conflict and Contradiction in a Peruvian Frontier Settlement. Ithaca: Cornell University Press, 1981.

Scott, James C. The Moral Economy of the Peasant: Rebellion and Subsistence in the Southeast Asia. New Haven: Yale University Press, 1976. - Weapons of the Weak: Everyday Forms of Peasant Resistance. New Haven: Yale University Press, 1985 .

Selligson, Mitchell A., ed. The Gap Between Rich and Poor: Contending Perspectives on the Political Economy of Development. Boulder: Westview Press, Inc., 1984.

Sheahan, John. Patterns of Development in Latin America: Poverty, Repression and Economic Strategy. Princeton: Princeton University Press, 1987.

Singelmann, Peter. Structures of Domination and Peasant Movements in Latin America. Columbia: University of Missouri Press, 1981. 
Skocpol, Theda. States and Social Revolutions: A

Comparative Analysis of France, Russia and China.

Cambridge: Cambridge University Press, 1979.

- Vision and Method in Historical Sociology.

Cambridge: Cambridge University Press, 1984.

Spalding, Karen, ed. Essays in the Political Economic and

Social History of Colonial Latin America. Newark,

Delaware: University of Delaware, 1982 .

Stepan, Alfred. The State and Society: Peru in Comparative

Perspective. Princeton: Princeton University Press, 1978 .

Stern, Steve J., ed. Resistance, Rebellion and

Consciousness in the Andean Peasant World, 18th to 20th

Centuries. Madison: University of Wisconsin Press, 1987 .

Swift, Jeannine. Economic Development in Latin America. New York: St. Martin's Press, 1978.

Thomas, Clive Y. The Rise of the Authoritarian State in Peripheral Societies. New York: Monthly Review Press, 1984 . 
Thorp, Rosemary and Geoffrey Bertram. Peru, 1880-1977: Growth and Policy in an Open Economy. New York: Columbia University Press, 1978.

Tulchin, Joseph S., ed. Problems in Latin American History: The Modern Period. New York: Harper and Row Publishers, 1973.

Walton, John. Reluctant Rebels: Comparative Studies of Revolution and Underdevelopment. New York: Columbia University Press, 1984 .

Weller, Robert P., and Scott E. Guggenheim, eds. Power and Protest in the Countryside: Studies of Rural Unrest in Asia, Europe and Latin America. Durham: Duke Press Policy Studies, 1982.

Whyte, William Foote, and Giorgio Alberti. Power Politics and Progress: Social Change in Peru. New York: Elsevier, 1976

Wilber, Charles K., ed. The Political Economy of Development and Underdevelopment. New York: Random House, Inc., 1988 .

Wolf, Eric R. Peasant Wars of the Twentieth Century. New York: Harper and Row, 1968. 
- Peasants. New Jersey: Prentice Hall,

\section{6.}

Wolpe, Harold, ed. The Articulation of Modes of Production: Essays from Economy and Society. London: Routledge and Kegan Paul, 1975.

Wright, Erik Olin. Classes. London: Verso, 1985.

Wright, Erik Olin, ed. The Debate on the Classes. London: Verso, 1989 .

Young, Clifford. The Politics of Cultural Pluralism. Madison: University of Wisconsin Press, 1976. 


\section{PERIODICALS}

Adas, Michael. "Moral Economy or Contest State?: Elite Demands and The Origins of Peasant Protest in Southeast Asia." Journal of Social History 13 , no. 4 (Summer 1980): 521-46.

Blanchard, Peter. "The Recruitment of Workers in the Peruvian Sierra at the Turn of the Century: The Engache System." Inter-American Economic Affairs 33, no. 3 (Winter 1980):63-83.

Bodemann, Michal Y. "Class Rule as Patronage: Kinship, Local Ruling Cliques and the State in Rural Sardinia." The Journal of Peasant Studies 9, no. 2 (January 1982): $147-75$.

Booth, John A. "Political Participation in Latin America: Levels, Structures, Context, Concentration and Rationality." Latin American Research Review 14, no. 3 : 29-59.

Brass, Tom. "Cargos and Conflicts: The Fiesta System and Capitalist Development in Eastern Peru." The Journal of Peasant Studies 13, no. 3 (April 1986): 45-62. 
"Class Formation and Class Struggle in La

Convencion, Peru." The Journal of Peasant Studies 7, no. 4 (July 1980): 427-57.

. "Trotskyism, Hugo Blanco and the Ideology of a Peruvian Peasant Movement." The Journal of Peasant Studies 16, no. 2 (Janury 1989): 173-97. - "Unfree Labor and Capitalist Restructuring in the Agrarian Sector: Peru and India." The Journal of Peasant Studies 1, no. 1 (October 1985): 50-77.

Brustein, William, and Margaret Levi. "The Geography of Rebellion: Rulers, Rebels and Regions, 1500-1700." Theory and Society 16, no. 4 (July 1987): 467-93.

Byres, T. J. "Modes of Production and Non-European, Pre-Colonial Societies: The Nature and Significance of the Debate." The Journal of Peasant Studies 12, nos. 2 and 3 (January/April 1985): 1-18.

Caballero, Jose Maria. "Agriculture and The Peasantry under Industrialization Pressures: Lessons from the Peruvian Experience." Latin American Research Review 19, no. $2(1984): 3-41$. 
Chevalier, Jacques M. "There is Nothing Simple about Simple Commodity Production." The Journal of Peasant Studies, 10, no. 4 (July 1983): 153-86.

Chinchilla, Norma Stoltz, and James Lowell Dietz. "Toward A New Understanding of Development and Underdevelopment." In Dependency and Marxism: Toward a Resolution of the Debate edited by Ronald H. Chilcote. Boulder, Colorado: Westview Press, 1982.

Eckstein, Susan. "Revolutions and the Restructuring of National Economies: The Latin American Experience." Comparative Politics 17, no. 4 (July 1985): 473-93.

Evans, Grant. "The Accursed Problem: Communists and Peasants." Peasant Studies 15, no. 2 (Winter 1988): 73-102.

Fisher, John. "Royalism, Regionalism, and Rebellion in Colonial Peru, 1808-1815." Hispanic American Historical Review 59, no. 2 (May 1979): 232-57.

Foster-Carter, Aidan. "The Modes of Production Controversy." The New Left Review 107 (January-February $1980): 47-77$. 
Galli, Rosemary. "Rural Development as Social Control: International Agencies and Class Struggle in the Colombian Countryside." Latin American Perspectives 5, no. 4 (Fall 1978): 71-89.

Gonzales, Michael J. "Recent Contributions to Andean Ethnohistory." Peasant Studies 12, no. 4 (Summer 1985): $287-93$.

Green, Jerold D. "Countermobilization as a Revolutionary Form." Comparative Politics 16, no. 2 (January 1984): 153-69.

Grieshaber, Erwin P. "Hacienda-Indian Community Relations and Indian Acculturation: An Historiographical Essay." Latin American Research Review 14, no. 3 (1979): 107-12.

Gudmundson, Lowell. "Peasant, Farmer, Proletariat: Class Formation in a Smallholder Coffee Economy, 1850-1950." Hispanic American Historical Review 69, no. 2 (May 1989): 221-57.

Harris, Richard. "Marxism and the Agrarian Question in Latin America." Latin American Perspectives 5, no. 4 (Fall 1978): 2-26. 
Henfrey, Colin. "Dependency, Modes of Production and the Class Analysis of Latin America." In Dependency and Marxism: Towards A Resolution of The Debate, Edited by Ronald H. Chilcote. Bolder, Colorado: Westview Press, 1982 .

Hobsbawm, E.J.E. "A Case of Neo-Feudalism: La Convencion, Peru." Journal of Latin American Studies 1, no. 1 $(1969): 31-50$.

Hunt, David. "Peasant Movements and Communal Property during the French Revolution." Theory and Society 17, no. $2($ March 1988): 255-83.

Jackson, Robert $\mathrm{H}$. "The Decline of the Hacienda in Cochabamba, Bolivia: The Case of the Sacaba Valley, 1870-1929." Hispanic American Historical Review 69, no. 2 (May 1989): 259-80.

Johnson, Howard. "Merchant Credit and the Dispossession of the Cocoa Peasantry in Trinidad in the Late Nineteenth Century." Peasant Studies 15, no. 1 (Fall 1987): 27-38.

Janvry, Alain de, and Lynn Ground. "Types and Consequences of Land Reform in Latin America." Latin American Perspectives 5, no. 4 (Fall 1978): 90-112. 
Kincaid, A.Douglas. "Peasants into Rebels: Community and Class in Rural El Salvador." Comparative Studies in Society and History 29, no. 3 (July 1987): 466-94.

Langer, Erik, D. "Labor Strikes and Reciprocity on Chuquisaca Haciendas." Hispanic American Historical Review 5 no. 2 (May 1985): 255-77.

Larson, Brooke. "Rural Rhythms of Class Conflict in Eighteenth-Century Cochabamba." Hispanic American Historical Review 60, no. 3 (August 1980): 407-30.

Lemarchand, Rene. "Political Clientelism and Ethnicity in Tropical Africa: Competing Solidarities in Nation-Building." The American Political Science Review 66, no. 1 (March 1972): 68-101.

Luong, Hy Van. "Agrarian Unrest from an Anthropological Perspective: The Case of Vietnam." Comparative Politics 17, no. 2 (January 1985): 153-71.

Mallon, Florencia E. "Peasants and Rural Laborers in Pernanbuco, 1955-1964." Latin American Perspectives, 5, no. 4(Fall1978): 49-69. 
Meillassoux, Claude. "The Economic Bases of Demographic Reproduction: From Domestic Mode of Production to Wage-Earning." The Journal of Peasant Studies 11, no. 1 (October 1983): 50-61.

Montoya, Rodrigo. "Changes in Rural Class Structure under the Peruvian Agrarian Reform." Latin American Perspectives 5, no. 4 (Fall 1978): 113-29.

Morner, Magnus. "Economic Factors and Stratification in Colonial Spanish America with Regard to Elites." Hispanic American Historical Review, 63 no.2 (May 1983): $335-69$.

"The Spanish American Hacienda: A Survey of Recent Research and Debate." Hispanic American Historical Review 53, no. 2 (May 1973): 183-216.

Neocosmos, Michael. "Marx's Third Class: Capitalist Landed Property and Capitalist Development." The Journal of Peasant Studies 13, no. 3 (April 1986): 5-44.

Piel, Jean. "The Place of the Peasantry in the National Life of Peru in the Nineteenth Century." Past and Present 46, (February 1970): 108-33. 
Popkin, Samuel. "The Rational Peasant: The Pollitical Economy of Peasant Society" Theory and Society 9, no. $3(1980)$ : $411-71$.

Portes, Alejandro. "Latin American Class Structures: Their Composition and Change during the Last Decades." Latin American Research Review 20, no. 3: 7-39.

Ramirez, Susan E. "The Dueno de Indios: Thoughts on the Consequences of the Shifting Bases of Power of the Curacas de los Viejos Antiguos under the Spanish in Sixteenth-Century Peru." Hispanic American Historical Review 67, no. 4 (November 1987): 575-610.

Rodrick, Dani. "Rural Transformation and Peasant Political Orientation in Egypt and Turkey." Comparative Politics 14, no. 4 (July 1982): 417-42.

Scott, C.D. "Peasants, Proletarianization and the Articulation of Modes of Production: the Case of Sugar Cane Cutters in Northern Peru, 1940-69." The Journal of Peasant Studies 3, no. 3 (April 1976): 321-41.

Scott, James C. "Hegemony and the Peasantry." Politics and Society 7 , no. 3 (1977): 267-96. 
"Patron-Client Politics and Political

Change in Southeast Asia." The American Political

Science Review 66, no. 1 (March 1972): 91-113.

- "Peasant Revolution: A Dismal Science."

Comparative Politics 9, no. 2 (January 1977):

231-48.

- "Protest and Profanation: Agrarian

Revolt and the Little Tradition." Parts 1 and 2.

Theory and Society 4, nos.1, 2 (Spring 1977): 1-38,

$211-46$.

- "Revolution in the Revolution: Peasants

and Commissars." Theory and society 7, nos. 1, 2

(January-March 1979): 97-134 .

Singelmann, Peter. "Rural Collectivization and Dependent

Capitalism: The Mexican Ejido." Latin American

Perspectives 5, no. 3 (Summer 1978): 38-59.

Skocpol, Theda. "Social Revolutions and Mass Military Mobilization." World Politics 40, no. 2 (January $1988): \quad 147-68$.

"What Makes Peasants Revolutionary?"

Comparative Politics 14, no. 3 (April 1982):

351-74. 
Soiffer, Stephen M, and Gary N. Howe. "Patrons, Clients and the Articulation of the Modes of Production: An Examination of the Penetration of Capitalism into Peripheral Agriculture in Northeast Brazil." The Journal of Peasant Studies 9, no. 2 (January 1982): 176-206.

Spalding, Karen. "Hacienda-Village Relations in Andean Society to 1830." Latin American Perspectives 2, no. 1 (Spring 1975): 107-21.

Stavenhagen, Rodolfo. "Capitalism and the Peasant in Mexico." Latin American Perspectives 5, no. 3 (Summer $1978): \quad 27-37$.

Stavig, Ward. "Ethnic Conflict, Moral Economy and Population in Rural Cuzco on the Eve of the Thupa Amaro II Rebellion." Hispanic American Historical Review 68, no. 4 (November 1988): 737-69.

Stinchcombe, Arthur. "Agricultural Enterprise and Rural Class Relations." The American Journal of Sociology 67, no. 2 (September 1961): 165-76.

Thompson, E.P. "The Moral Economy of the English Crowd in the Eighteenth Century." Past and Present 50, (February 1971): 76-132. 
Young, Eric Van. "Islands in the Storm: Quiet Cities and Violent Countrysides in the Mexican Independence Era." Past and Present 97, no. 118 (February 1988): $130-55$. 


\section{UNPUBLISHED PAPER}

Craig, Wesley William. "From Hacienda to Community: An Analysis of Solidarity and Social Change in Peru." Ph.D. diss., Cornell University, 1967. 